\title{
Deformite analiz ve planlama prensipleri
}

\author{
The principles of deformity planning and analysing
}

\author{
Mustafa Kürklü, Mustafa Başbozkurt, Burak Abay
}

Memorial Sağlık Grubu, Bahçelievler Hastanesi, Ortopedi ve Travmatoloji Kliniği, İstanbul

\begin{abstract}
Bu derleme deformite analizi ve planlamasına genel bir bakış açısı sağlamaktadır. Deformite analizinde farklı metodlar kullanılırken, değişmeyen parametre doğru radyografi çekimidir. Deformite basitten komplekse geniş bir yelpaze içerirken, radyografik olarak frontal ve sagittal planlar mutlak değerlendirilmektedir. Bir ortopedik cerrahın deformite planlaması için öncelikle ekstremitenin normal parametrelerini bilmesi gerekmektedir.
\end{abstract}

Anahtar sözcülkler: deformite; analiz; planlama
This article will provide a general review of deformity analysis and deformity planning. Several techniques are used in deformity analysis; however precise radiography is essential. Deformities range from basic to complex deformities, and they are evaluated radiologically in both frontal and sagittal planes. The orthopedic surgeon must know normal parameters of the extremities to assess deformity planning.

Key words: deformity; analysis; planning

Deformite analizinde ekstremitenin üç temel anatomik planından bahsedilmektedir.
1. Frontal plan
2. Sagittal plan
3. Transvers plan

Ekstremiteyi oluşturan her uzun tübüler kemik anatomik ve mekanik olarak adlandırılan iki aksa sahiptir.

Uzun kemiğin mekanik aksı proksimal ve distal eklem merkezlerini birleştiren çizgi, anatomik aksı ise kemik diafizinin orta noktalarını birleştiren çizgi tarafından oluşturulmaktadır.

Femur anatomik ve mekanik aksı femurun anatomik yapısından dolayı farklı ve aralarında yaklaşık $7^{\circ}$ 'lik açı farkı var iken, tibianın anatomik ve mekanik aksı paralel olup aynı kabul edilmektedir (Şekil 1).

Mekanik aks çizgileri eklemlerin merkezinden geçmektedir. Eklem merkezlerinin belirlenmesi Moreland ve ark.'nın tanımladığı şekilde saptanmaktadır. Kalça eklem merkezi daire şeklinde olan femur başının orta noktası iken, dizde üç farklı şekilde eklem orta noktası bulunmaktadır. Birincisi femoral noç (çentik) tepe noktası, ikincisi femoral kondilleri birleştiren çizginin

- Illetişim adresi: Prof. Dr. Mustafa Kürklü, Bahçelievler, Eski Londra Asfaltı Cd. No:227, 34180 Bahçelievler, İstanbul Tel: 0505 - 7853781 e-posta: kurklumd@yahoo.com

- Geliș tarihi: 6 Aralık 2019 Kabul tarihi: 24 Ocak 2020 


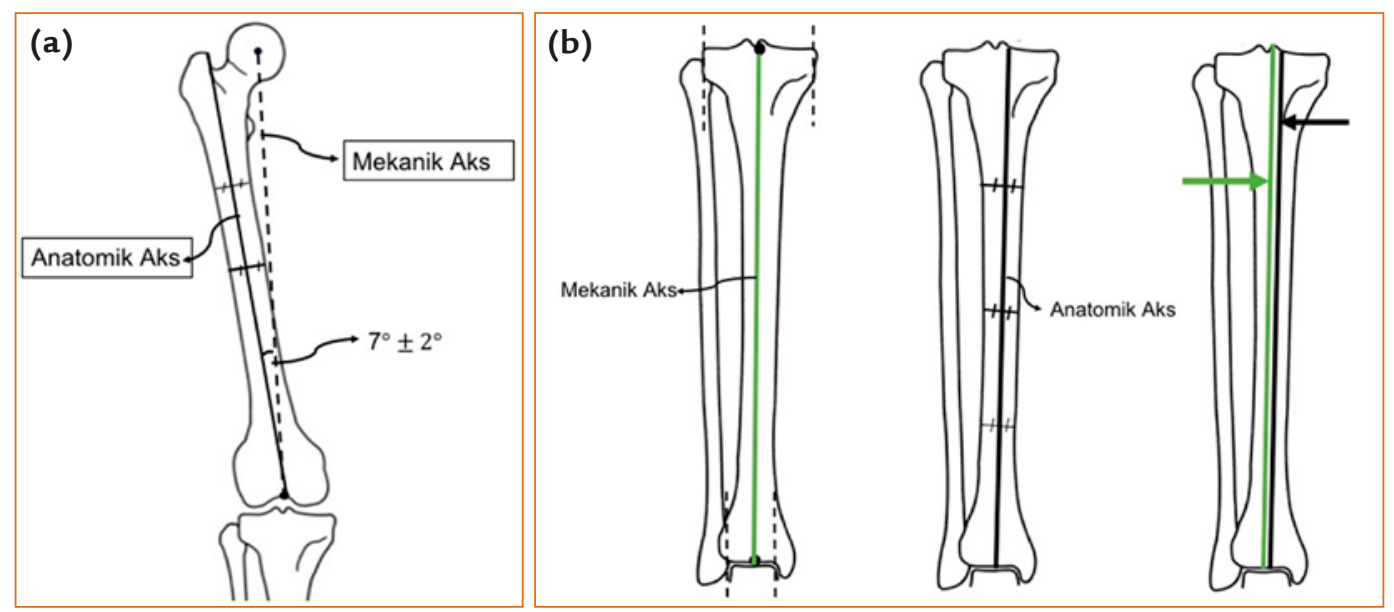

Şekil 1. a, b. Femur anatomik ve mekanik aksı (a). Tibianın anatomik ve mekanik aksı (b).
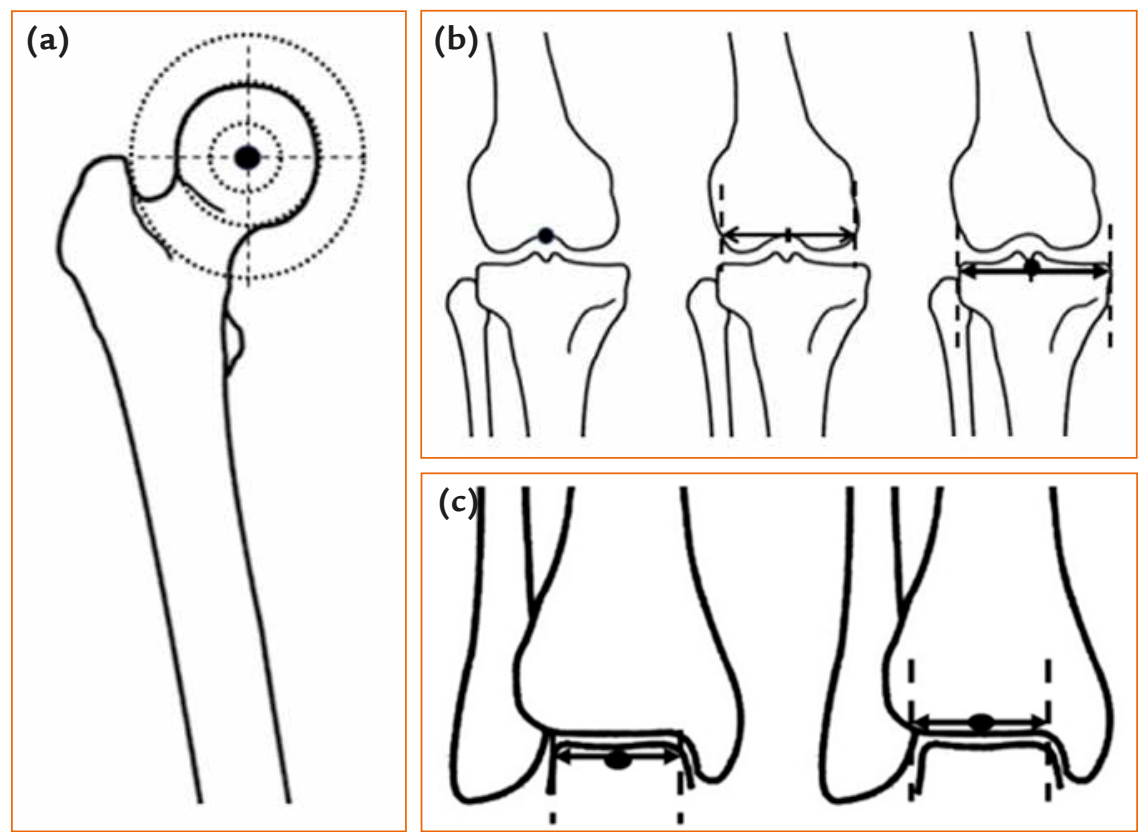

Şekil 2. a-c. Femur başı merkezi (a). Diz eklem merkezi üç farklı şekilde belirlenebilir (b). Ayak bilek eklem merkezi (c).

orta noktası, üçüncüsü ise tibial platonun orta noktasıdır ve hepsi diz eklemi orta noktası olarak tanımlanmaktadır. Ayak bileği orta noktası ise iki şekilde tanımlanmaktadır. Talus eklem yüzeyinin orta noktası ya da tibia ve fibula tarafindan oluşturulan plafond ekleminin orta noktasıdır (Şekil 2). ${ }^{[1,2]}$

Deformite analizinde mekanik ya da anatomik aks ve oryantasyon çizgileri birlikte eklem oryantasyon açılarını oluşturmaktadır. Bu çizgilerin tarifi; kalça ekleminde frontal planda femur başı merkezinden trokanter majör tepe noktasına çizilen çizgi iken, sagittal planda trokanter majörün iki tepe noktasını birleştiren çizgidir. Diz frontal plan oryantasyon çizgisi medial ve lateral tibial platonun konkav noktalarını birleştiren çizgi ya da femur medial ve lateral kondil konveks noktalarını birleştiren çizgi olarak tanımlanmaktadır. Sagittal planda ise tibia platosunu subkondral olarak geçen çizgi tibianın diz eklemi oryantasyon çizgisi iken, femurda kondillerin diyafiz ile birleşme noktalarını birleştiren çizgi olarak tanımlanmıştır. Çocuklarda femur distali oryantasyon çizgisi büyüme plağının uç noktalarını birleştiren çizgidir. Ayak bileği frontal plan oryantasyon çizgisi distal tibia eklemi subkondral çizgisi ya da talus subkondral çizgisi iken, sagittal planda tibia eklem dudaklarının anterior ve posterior noktalarını birleştiren çizgidir (Şekil 3). ${ }^{[1-3]}$ 

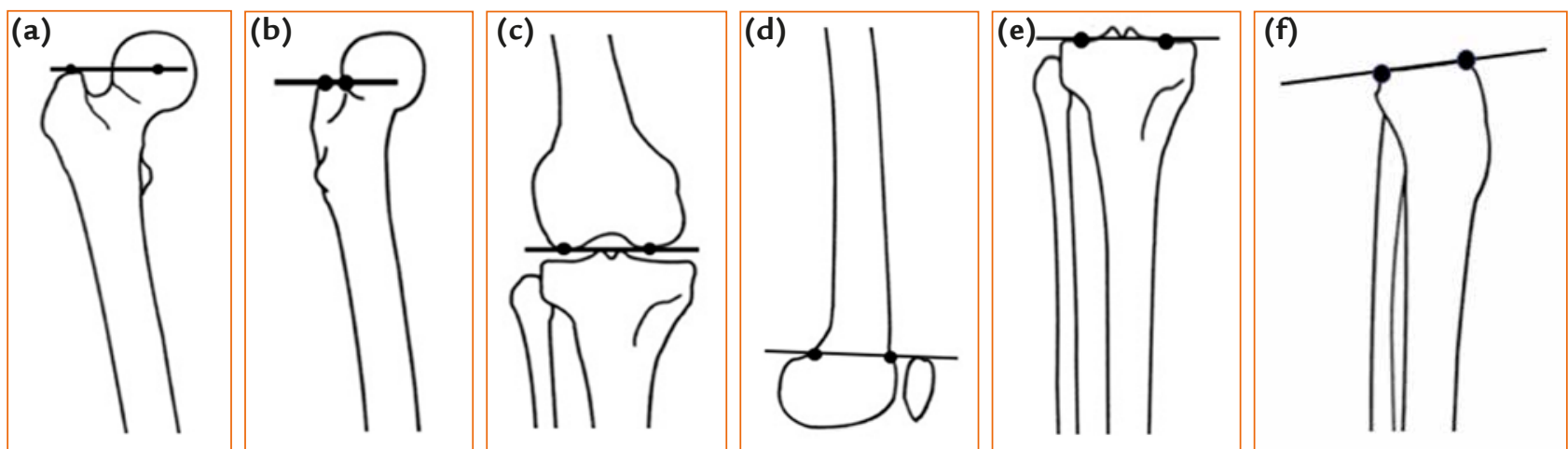

Şekil 3. a-f. Kalça eklemi frontal plan oryantasyon çizgisi (a). Kalça eklemi sagittal plan oryantasyon çizgisi (b). Femur distali frontal plan oryantasyon çizgisi (c). Femur distali sagittal plan oryantasyon çizgisi (d). Tibia proksimal frontal plan oryantasyon çizgisi (e). Tibia proksimal sagittal plan oryantasyon çizgisi (f).

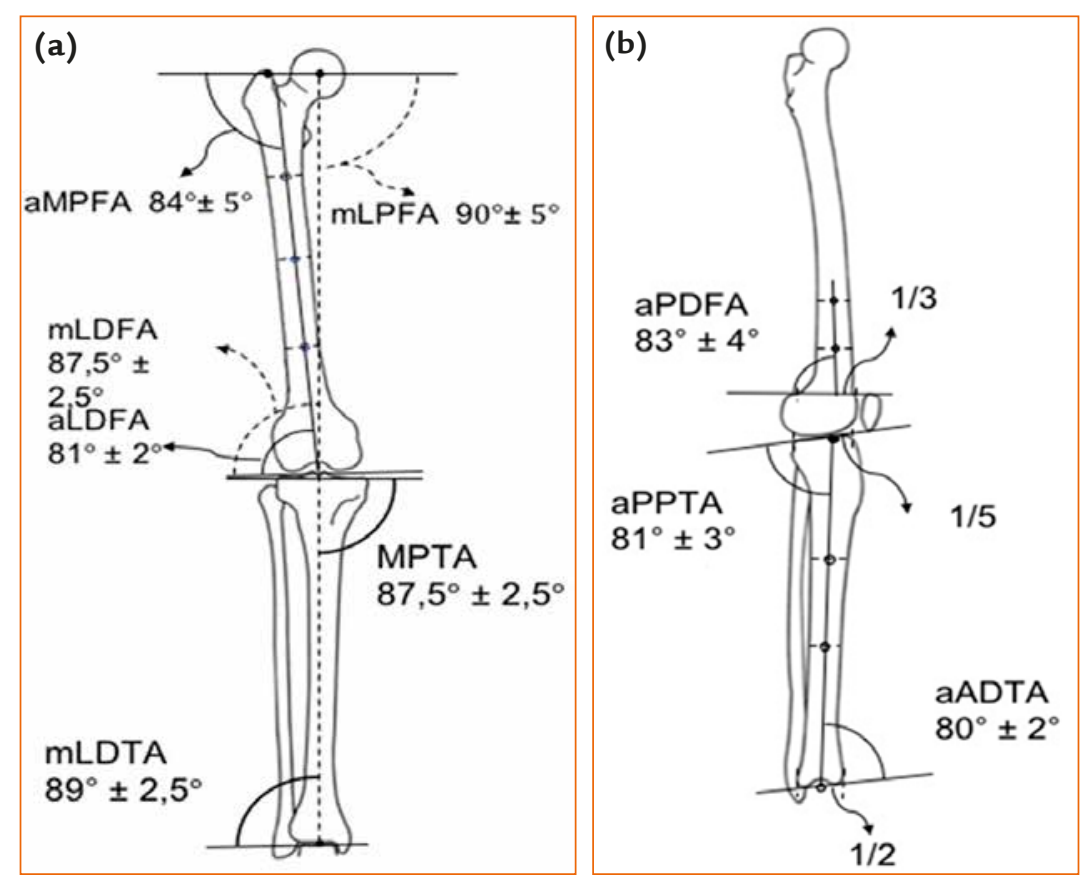

Şekil 4. a, b. Alt ekstremite frontal plan mekanik ve anatomik aksı ve açıları (a). Alt ekstremite sagittal plan mekanik ve anatomik aksı ve açıları (b).

\section{Eklem Oryantasyon Açıları ve İsimlendirilmesi}

Frontal ve sagittal planda mekanik ya da anatomik aks çizgileri ile eklem oryantasyon çizgilerinin kesişmesi ile eklem oryantasyon açıları oluşmaktadır. Bu açıların isimleri dört büyük harften ve önlerine gelen bir küçük harften oluşmaktadır. Dört büyük harfin önüne gelen ' $a$ ' harfi açının anatomik eksene göre çizildiğini, ' $m$ ' harfi ise açının mekanik eksene göre çizildiğini göstermektedir. Dört büyük harften birincisi açının yönünü tanımlar. Eğer açı frontal planda elde edilmiş ise lateral $(L)$ ya da medial $(M)$ olur iken, sagittal planda elde edilmiş ise ise anterior $(A)$ ya da posterior $(P)$ olarak belirtilir. İkinci büyük harf açının kemiğin proksimalinde $(P)$ ya da distalinde (D) olduğunu göstermektedir. Üçüncü büyük harf açının femur $(F)$ ya da tibia $(T)$ segmentlerinden birine ait olduğunu gösterirken, dördüncü büyük harf hepsinde aynıdır ve açı $(A)$ kelimesinin baş harfidir. Frontal planda mekanik lateral distal femoral açı (mLDFA) olarak ifade edilirken, anatomik lateral distal femoral açı (aLDFA) olarak ifade edilmektedir. Sagittal planda açıların adlandırılması da aynı şekildedir. Örneğin, anatomik posterior proksimal tibial açı (aPPTA) sagittal planda tibia proksimal posterior oryantasyon açısını ifade etmektedir (Şekil 4). ${ }^{[1-3]}$ 

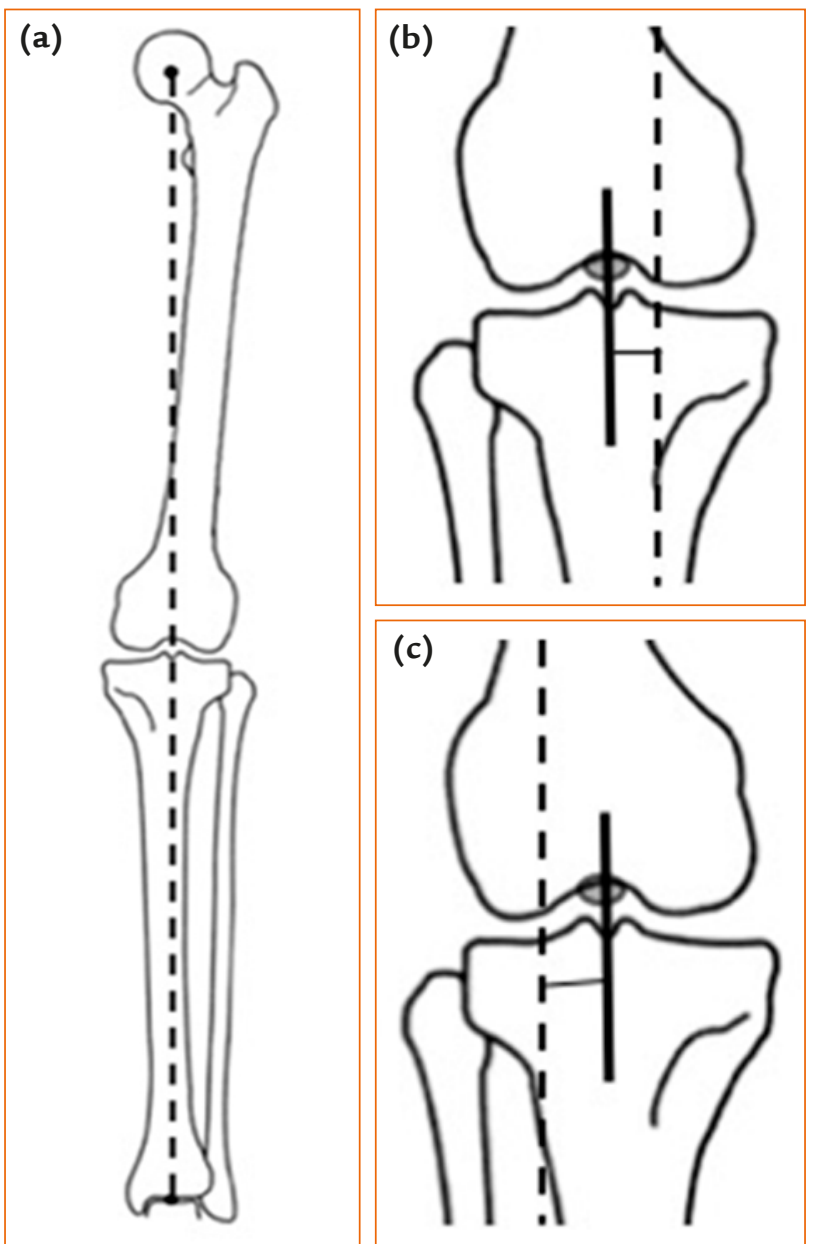

Şekil 5. a-c. Mekanik aksın diz eklemi ile ilişkisi (a). Mekanik aksın medial deviasyonu (b). Mekanik aksın lateral deviasyonu (c).

\section{Mekanik Aks ve Mekanik Aks Deviasyonu}

Alt ekstremite frontal plan değerlendirilmesinde eklem dizilimi ve eklem oryantasyonu önemlidir. Frontal planda femur başı merkezinden ayak bilek eklem merkezine çizilen doğru alt ekstremite mekanik aksı olarak adlandırılır. ${ }^{[2-5]}$ Mekanik aks çizgisinin diz eklem merkezinden uzaklığı mekanik aks deviasyonu (MAD) olarak adlandırılır. Alt ekstremite mekanik ekseninin dizin merkezinden $15 \mathrm{~mm}$ kadar medialden geçmesi normal kabul edilir. Ancak mekanik eksen 15 mm'den daha fazla medialden geçiyorsa mekanik aks deviasyonu (MAD) olarak adlandırılır. MAD medialde ve 15 mm'den büyükse varus deformitesi söz konusudur. Alt ekstremitenin mekanik ekseni dizin merkezini lateral geçiyorsa (1 $\mathrm{mm}$ ve üzeri) MAD olarak adlandırılır ve valgus deformitesi olarak adlandırılır (Şekil 5). ${ }^{[2-5]}$
Frontal Planda Malalignment (Dizilim Bozukluğu) ve Maloryantasyon (Eklem Uyum Bozukluğu)

Malalignment frontal planda kalça, diz ve ayak bileği ekleminin doğru diziliminin olmaması olarak tanımlanır. MAD normal sınırların dışında olması kalça, diz ya da ayak bilek ekleminde malalignment olduğunu göstermektedir. Frontal planda MAD dört farklı anatomik bölgeden kaynaklanmaktadır. ${ }^{[2,3]}$ Bunlar;
1. Femoral frontal plan deformitesi
2. Tibial frontal plan deformitesi
3. Frontal plan diz eklem laksitesi
4. Femoral ya da tibial kondil yetmezliği

\section{Malalignment Test}

Bu test de femur başı merkezinden ayak bileği merkezine frontal plan mekanik aksı çizilir. Bu çizgi dizin merkezinin ortalama $8 \pm 7 \mathrm{~mm}$ medialinden geçer. $M A D$ varlığı deformite varlığını göstermektedir.

\section{Malalignment test 1 (femoral frontal plan deformitesi)}

Bu testte, "Deformite femurda mı?" sorusunun cevabı araştırılır. Bunun için mekanik lateral distal femoral açı (mLDFA) ölçülür. Femur başı merkezini femur distal eklem yüzü merkezi ile birleştiren femur mekanik ekseni çizilir. Sonra femur medial ve lateral kondillerinin en alt subkondral noktaları birleştirilerek distal femur oryantasyon hattı çizilir. Bu şekilde elde edilen açı mLDFA olup, bu açı normalde $87,5^{\circ} \pm 2,5^{\circ}$ 'dir.

$\mathrm{Bu}$ açı belirtilen değerlerin dışında ise deformite varlığını gösterir. Açı $90^{\circ}$ 'den büyükse femur varus deformitesinden, açı $85^{\circ}$ 'den küçük ise femur valgus deformitesinden bahsedilmektedir (Şekil 6). ${ }^{[2-5]}$

\section{Malalignment testi 2 (tibial frontal plan deformitesi)}

Bu testte, "Deformite tibiada mı?" sorusunun cevabı aranır. Bunun için medial proksimal tibial açı (MPTA) ölçülür. Tibia proksimal eklem yüzü merkezi, tibia distal eklem yüzü merkezi ile birleştirilerek tibia mekanik ekseni çizilir. Sonra tibial platoların subkondral noktaları birleştirilerek proksimal tibia oryantasyon hattı çizilerek tibia medialinde MPTA elde edilir. Bu açı normalde $87,5^{\circ} \pm 2,5^{\circ}$ 'dir.

$\mathrm{Bu}$ açı $85^{\circ}$ 'den küçükse tibiada varus deformitesi, $90^{\circ}$ 'den büyükse tibiada valgus deformitesi olarak adlandırılmaktadır (Şekil 7). ${ }^{[2-5]}$

\section{Malalignment testi 3 (frontal plan diz eklem laksitesi)}

Bu testte, "Deformite diz ekleminde mi?" sorusunun cevabı araştırılır. Bunun için, femoral ve tibial diz eklem oryantasyon çizgileri arasında joint line convergence angle=diz eklem uyum açısı (JLCA) ölçülür. 


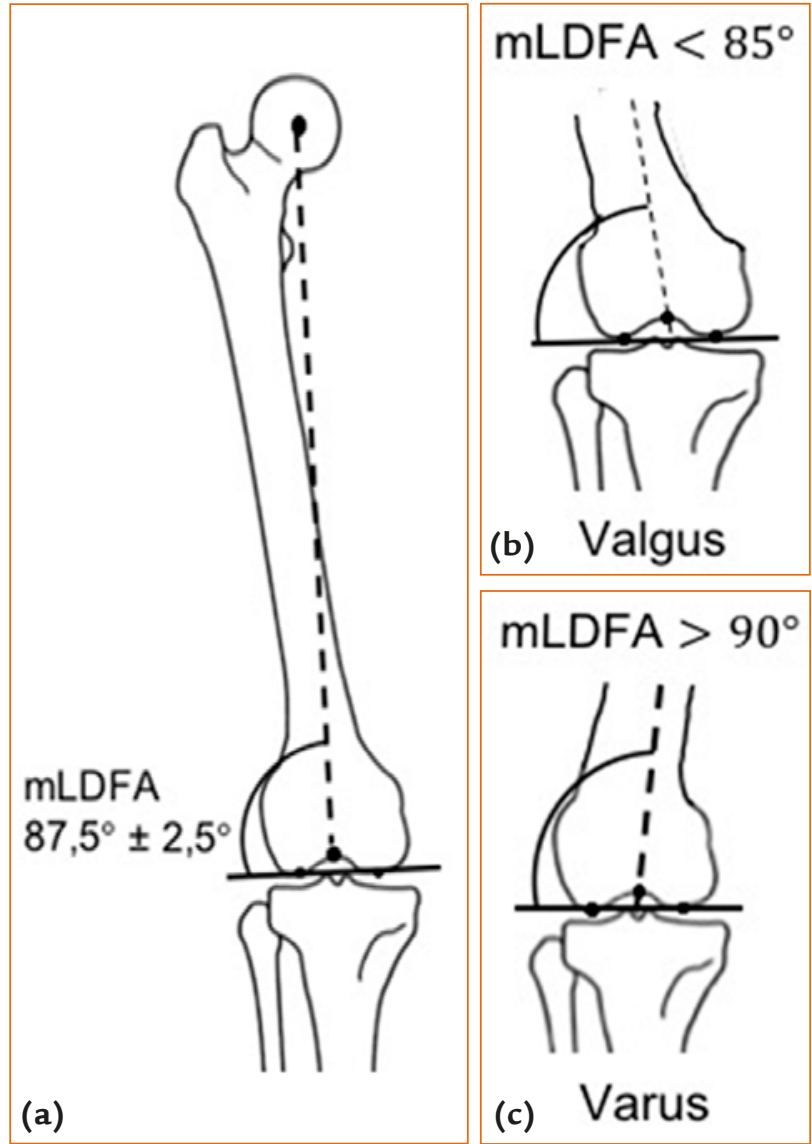

Şekil 6. a-c. Femur mekanik aksı ve mLDFA (a). Femur distali valgus deformitesi (b). Femur distali varus deformitesi (c).

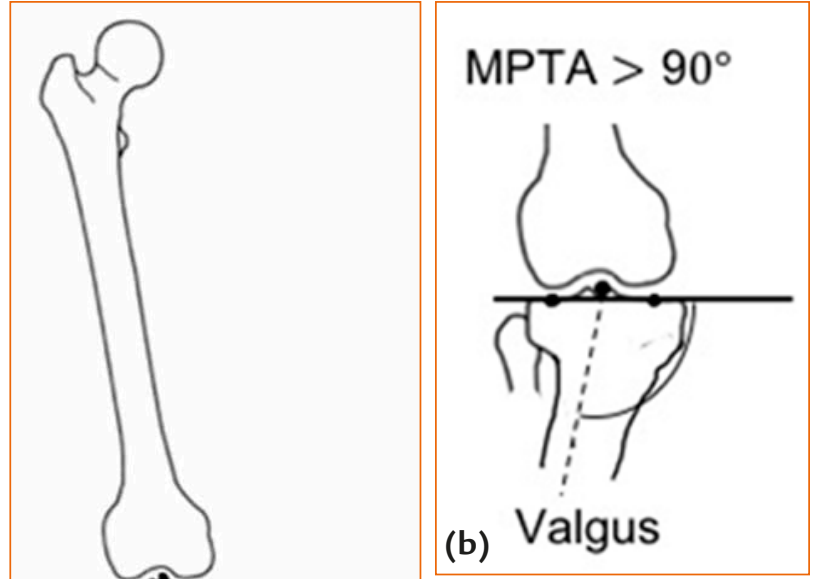

(a)

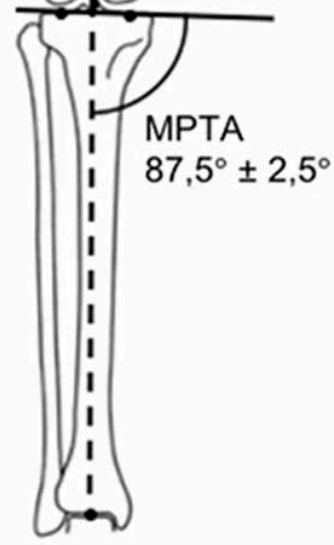

MPTA $<85^{\circ}$

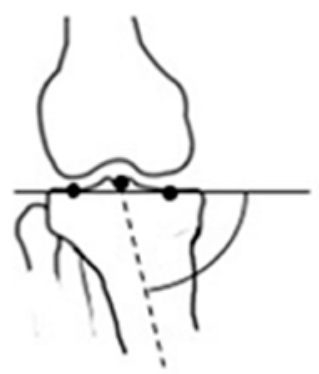

(c)

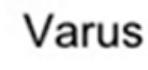

Şekil 7. a-c. Tibia mekanik aksı ve MPTA (a). Tibia proksimal valgus deformitesi (b). Tibia proksimal varus deformitesi (c).
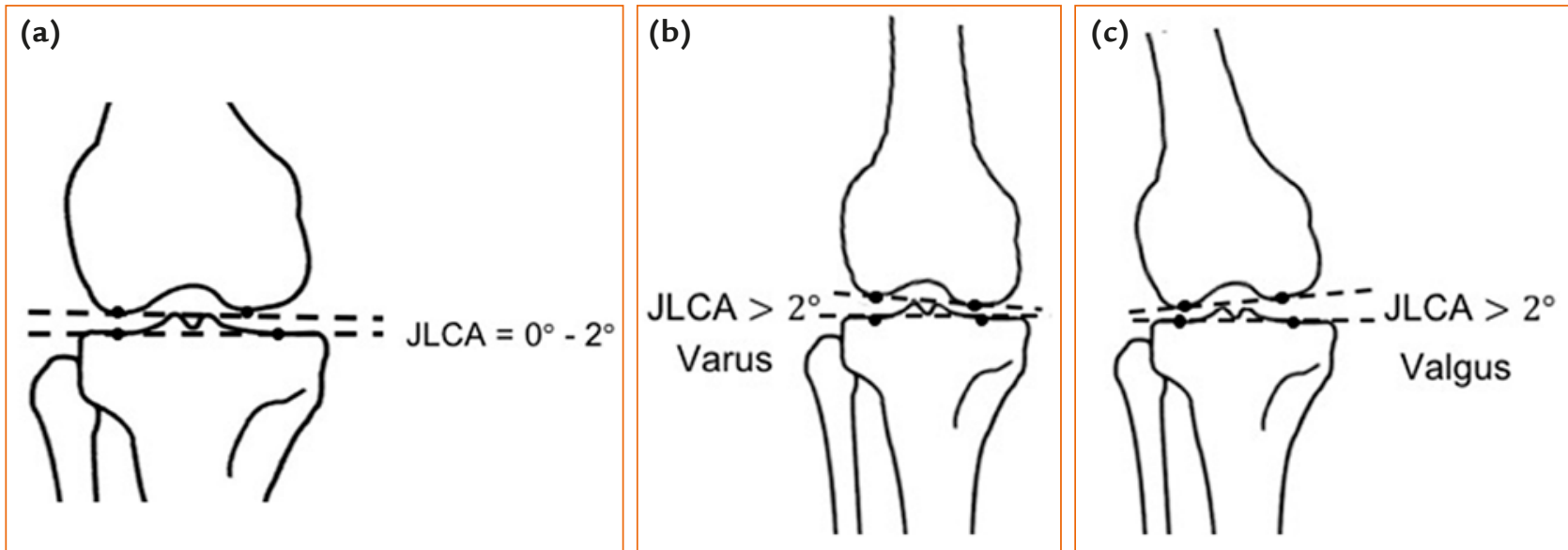

Şekil 8. a-c. Joint line convergence angle = Diz eklem uyum açısı (a). Diz ekleminde varus deformitesi (b). Diz ekleminde valgus deformitesi (c).

Distal femur oryantasyon hattı ve tibia oryantasyon hattı çizilir. Bu iki çizgi birbirine paraleldir. Aralarında $2^{\circ}$ ye kadar açı olabilir. Bu açı $2^{\circ}$ 'den daha büyük olursa deformitenin diz ekleminde olduğunu gösterir.
$\mathrm{Bu}$ açı $2^{\circ}$ 'den büyükse ve medialde ise diz ekleminde valgus deformitesi, $2^{\circ}$ 'den büyükse ve lateralde ise diz ekleminde varus deformitesi olarak tanımlanır (Şekil 8). 


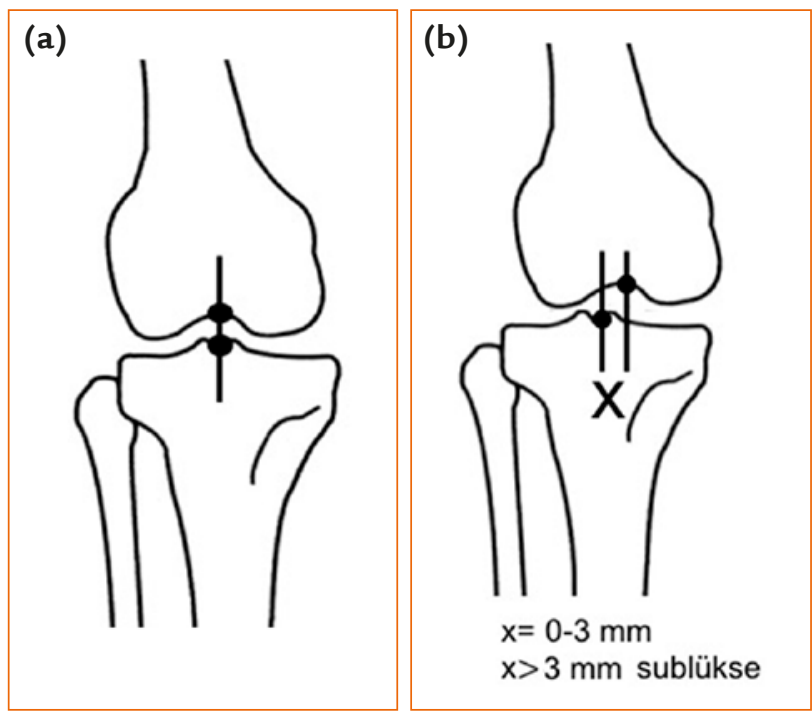

Şekil 9. a, b. Diz eklemi subluksasyon araştırılması (a). Sapma $3 \mathrm{~mm}$ ve altında ya da $3 \mathrm{~mm}$ ve üzerinde (b).

Takiben diz ekleminde subluksasyon varlığı araştırılır. Bunun için femur distal eklem yüzü ile tibia proksimal eklem yüzüne kenarlardan dik çizgiler çizilir ve bu dik çizgiler arasındaki mesafenin orta noktaları işaretlenir. Bu iki nokta normalde aynı hizada bulunmalıdır ancak aralarında $3 \mathrm{~mm}$ kadar sapma normal olarak kabul edilir. Üç mm'den fazla sapma varsa malalignment sebebi diz subluksasyonudur (Şekil 9). ${ }^{[2-5]}$

\section{Malalignment testi 4 (femoral ya da tibial kondil yetmezliği)}

Her iki femoral kondil ve her iki tibial platonun eklem yüzeyleri oryantasyon çizgileri çizilir. Her iki tibial platonun eklem yüzey çizgileri birbirini takip eder ve aralarında basamaklanma yoktur. Tibial plato yüzeyleri arasında, paralellik bozulmuşsa yani basamaklanma varsa kondiler malalignment söz konusudur. Aynı kriterler femoral kondiller için de geçerlidir, ancak femoral kondiller yuvarlak olduğundan tibial platoda olduğu kadar anlamlı olmayabilir (Şekil 10). ${ }^{[2-5]}$

\section{Frontal Plan Maloryantasyon Testi (MOT)}

Diz eklemi eklem yüzeylerinde maloryantasyon varlığında MAD meydana gelmektedir. Bu durumu belirlemek için MAT (malalignment testi) kullanılmaktadır. MAT diz ekleminde mekanik eksen sapması ile birlikte maloryantasyonu da ortaya çıkarmaktadır. Kalça ve ayak bileği ekleminde MAT doğru sonucu vermeyebilir. Tibia distal uçta ve femur proksimal uçta, kalça ve ayak bilek merkezlerine yakın deformite varlığında, mekanik aks deviasyonu (MAD) genellikle

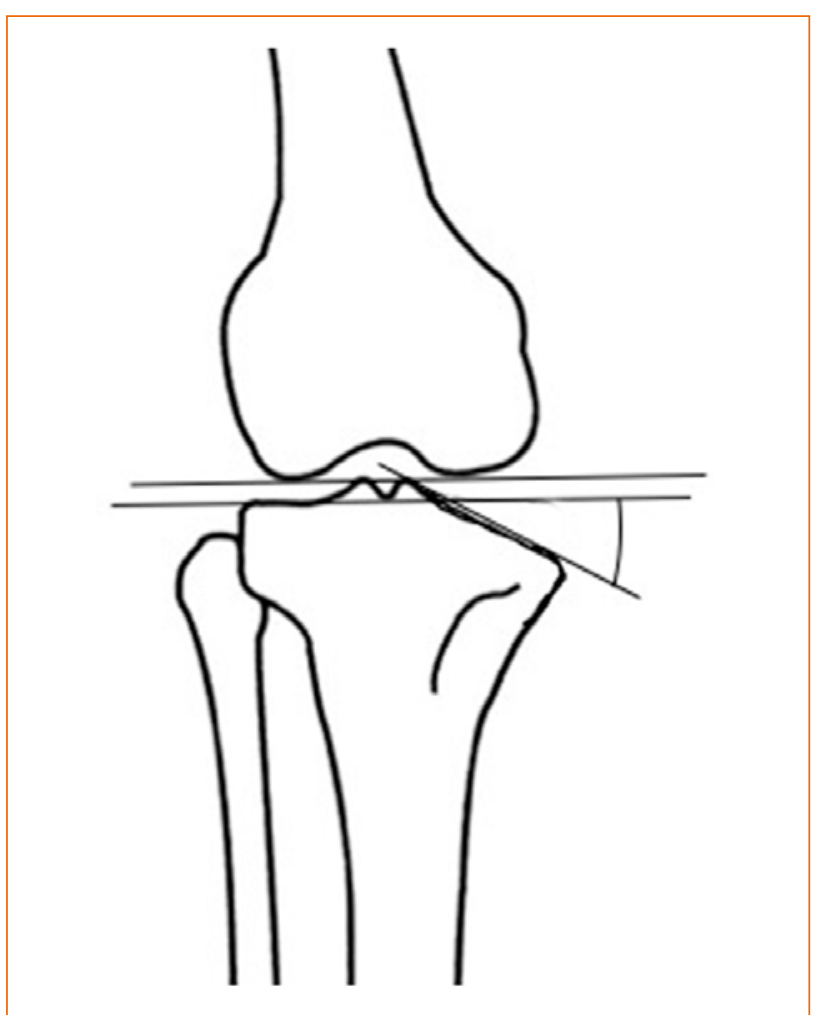

Şekil 10. Tibial plato malalignment testi.

saptanamayabilir. Bu nedenle kalça ve ayak bileğine yakın bölgelerde olan deformite MAT ile ortaya konamaz. Deformite analizini doğru sonuçlandırmak için MAT yaptıktan sonra kalça ve ayak bileği MOT'u yapmak gerekmektedir. ${ }^{[2-5]}$

\section{Kalça eklemi MOT testi}

Üç farklı şekilde kalça eklemi maloryantasyon testi yapılmaktadır.

Birincisi; Kalça eklemi oryantasyon çizgisi femur mekanik ekseni ile birleştirilir. Lateralde oluşan açı $85^{\circ}$ 'den küçükse koksa valga, $95^{\circ}$ 'den büyükse koksa vara deformitesi olarak tanımlanır (Şekil 11)

íkincisi; Kalça eklemi oryantasyon çizgisi femur anatomik ekseni ile birleştirilerek medialde aMPFA elde edilir. Açının normal değeri $84^{\circ}$ 'dir $\left(79^{\circ}-89^{\circ}\right)$. medialde oluşan açı $79^{\circ}$ 'den küçükse koksa vara, $89^{\circ}$ 'den büyükse koksa valga deformitesi olarak tanımlanır (Şekil 12).

Üçüncüsü; Femur başı merkezi ile femur boyun orta noktası bir çizgi ile birleştirilir. Femur anatomik ekseni çizilir ve medialde aMNSA açısı oluşur ve normal 


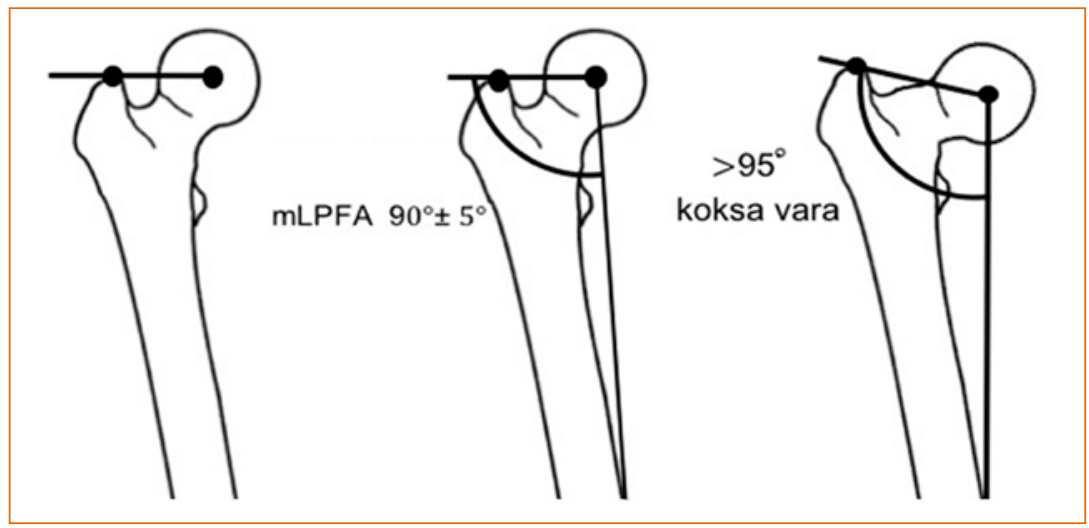

Şekil 11. Mekanik aksa göre kalça maloryantasyon testi.

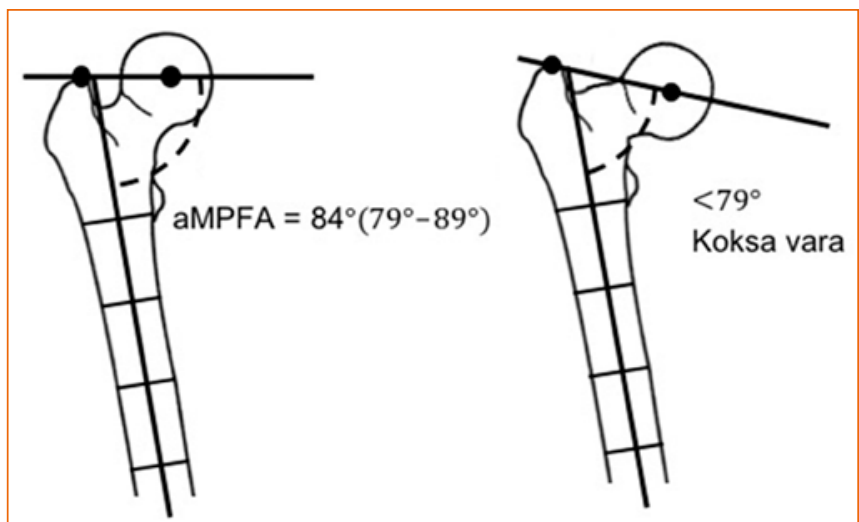

Şekil 12. Anatomik aksa göre kalça maloryantasyon testi.

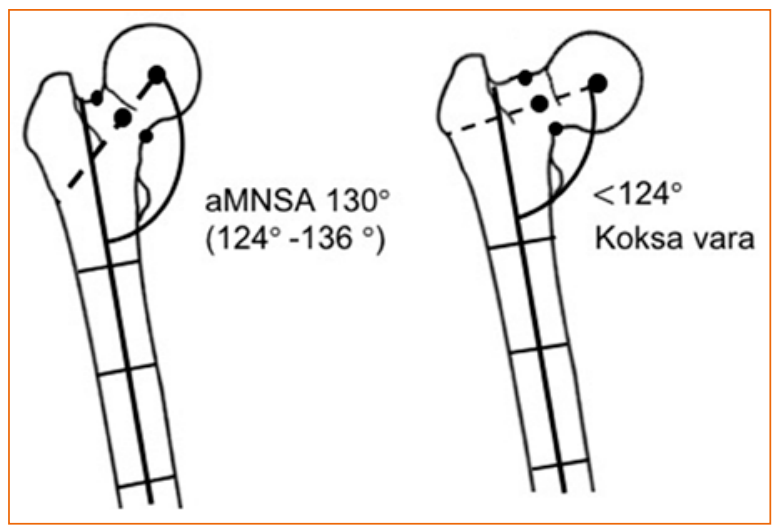

Şekil 13. Femur boyun çizgisi ile kalça maloryantasyon testi.

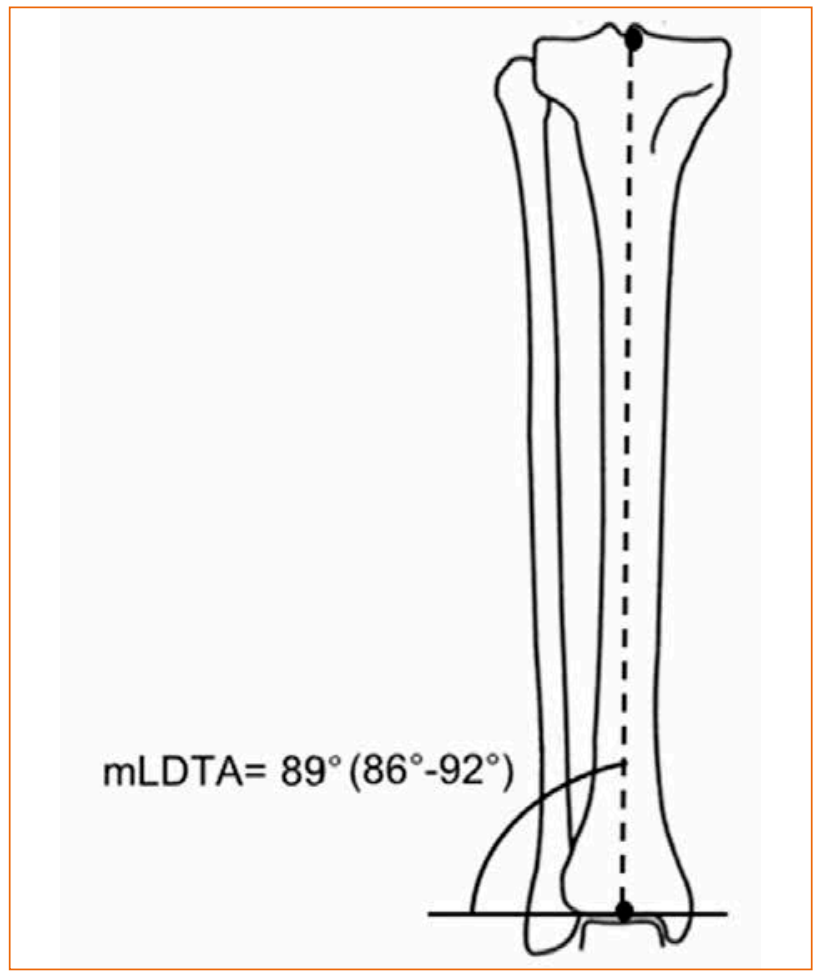

Şekil 14. Ayak bilek maloryantasyon testi. değeri $130^{\circ}$ dir $\left(124^{\circ}-136^{\circ}\right)$. Açı $124^{\circ}$ 'den küçükse koksa vara, $136^{\circ}$ 'den büyükse koksa valga deformitesi olarak tanımlanır (Şekil 13). ${ }^{[1-3]}$

\section{Ayak bilek eklem MOT testi}

Distal tibia eklemi oryantasyon çizgisi ile tibia anatomik veya mekanik ekseni çizilir. Lateralde oluşan LDTA normalde $89^{\circ}$ 'dir $\left(86^{\circ}-92^{\circ}\right)$. Açı $86^{\circ}$ den küçükse valgus, $92^{\circ}$ 'den büyükse varus deformitesi olarak tanımlanır (Şekil 14).

\section{Frontal Plan Deformite Analizi}

Femur ya da tibia frontal plan deformitesi yanlızca kemikte değil aynı zamanda onların akslarında olan angülasyondur. Deformitenin proksimal ve distal segmentleri anatomik ya da mekanik aksla ayrı ayrı değerlendirilir. Proksimal ve distal segment aks çizgilerinin kesişim noktası CORA (center of rotation of angulation) olarak adlandırılır. CORA proksimal segment aksı, proksimal mekanik aks (PMA) ya da proksimal 


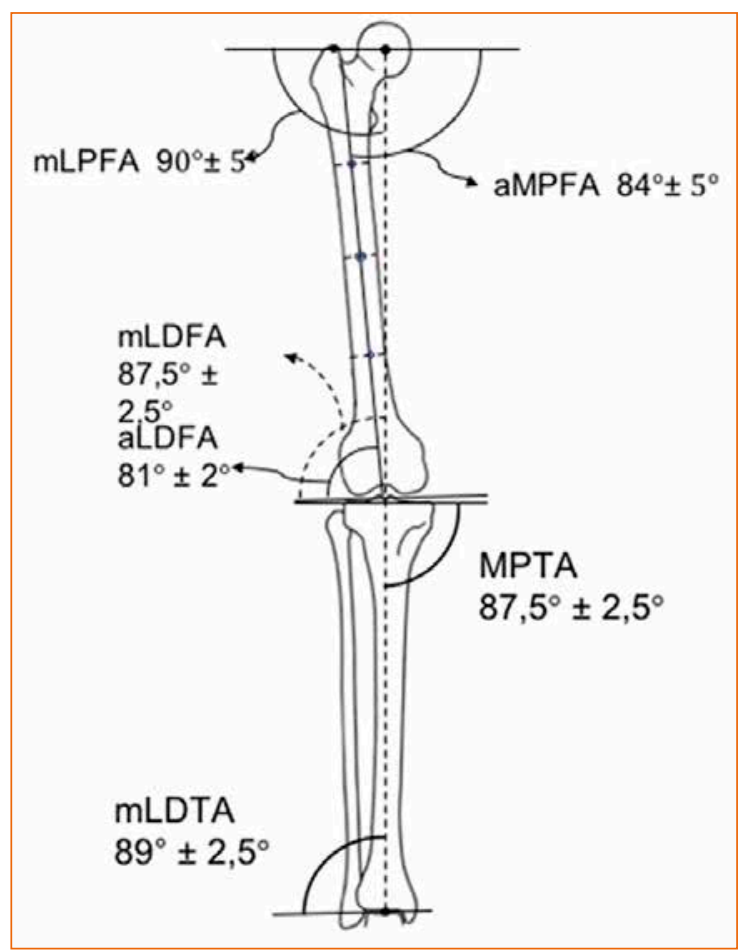

Şekil 15. Diz eklemi maloryantasyon testi.

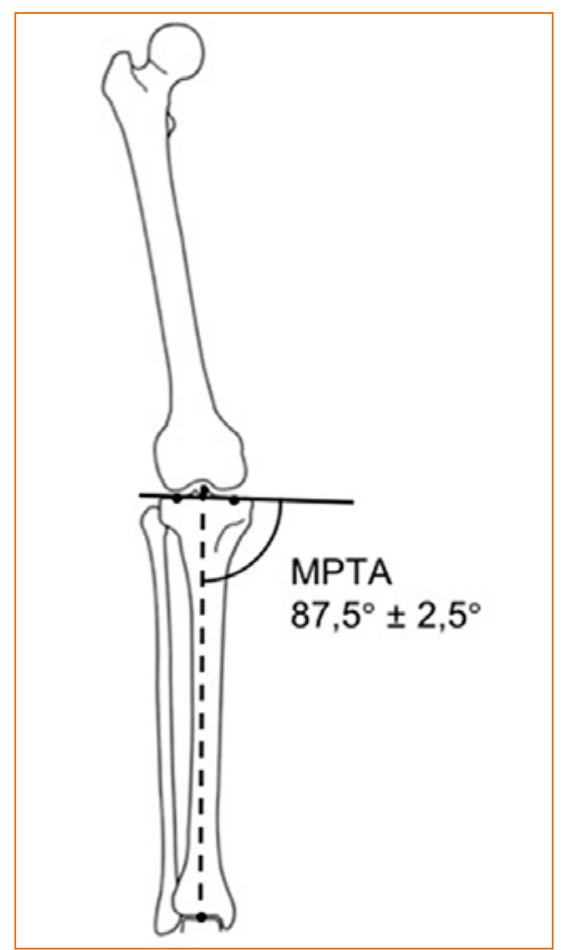

Şekil 16. Tibia proksimal mekanik aksı. anatomik aks (PAA) olarak adlandırılırken, distal mekanik aksı (DMA) ya da distal anatomik aks (DAA) olarak adlandırılır. ${ }^{[1-3]}$

CORA ile frontal plan mekanik ve anatomik aksları kullanılarak deformite analiz stepleri (basamakları) şu şekilde ilerlemektedir.

\section{Step (basamak) $0=$ maloryantasyon testi (MAT)}

Her iki alt ekstremitenin mekanik aksları çizilerek MAD saptanır. Daha sonra mLDFA, MPTA ve eklem uyumu (JLCA) her iki taraf ekstremitede değerlendirilir. Bu açılar ve uyum normal ise deformite yok kabul edilir, ancak hangi segmentde açı normal sınırların dışında ise onun mekanik ve anatomik aksları ve eklem oryantasyon çizgileri ile oluşan açıları değerlendirilir ve deformite saptanır (Şekil 15). ${ }^{[2,3]}$

\section{Tibial Deformite Değerlendirilmesi}

\section{Step (basamak) 1}

Proksimal tibial segment mekanik aks çizilmesi (Şekil 16);

1. Eğer mLDFA normal ise femur mekanik aksı tibia proksimal mekanik aksı olacak şekilde devam ettirilir. Bunun için JLCA normal olmalı.
2. mLDFA normal değerlerin dışında ve karşı taraf MPTA normal ise, proksimal tibia eklem oryantasyon çizgisine aynı açı ile mekanik aks çizgisi çizilir.

3. Hem mLDFA hem de MPTA normal değerlerin dışında ise, ortalama normal MPTA değeri kullanılarak proksimal segment mekanik aksı çizilir.

\section{Step (basamak) 2}

Distal tibial segment mekanik aksının çizilmesi (Şekil 17). ${ }^{[1-4]}$

1. Distal tibial segmentte deformite yoksa en az iki mid-diyafizel nokta alınarak ayak bilek oryantasyon çizgi orta noktasından geçen mekanik aks çizilir ve LDTA normal olduğu kontrol edilir.

2. Distal tibial diafiz normal değil ise karşı taraf LDTA değeri alınarak ayak bilek oryantasyon çizgisi orta noktasından aynı açı ile distal tibial segment mekanik aksı çizilir.

3. Distal tibial diyafizde deformite var ve karşı taraf LDTA değeri normal sınırlarda değil ise LDTA $90^{\circ}$ kabul edilerek ayak bilek oryantasyon çizgi orta noktasında mekanik aks çizilir. 


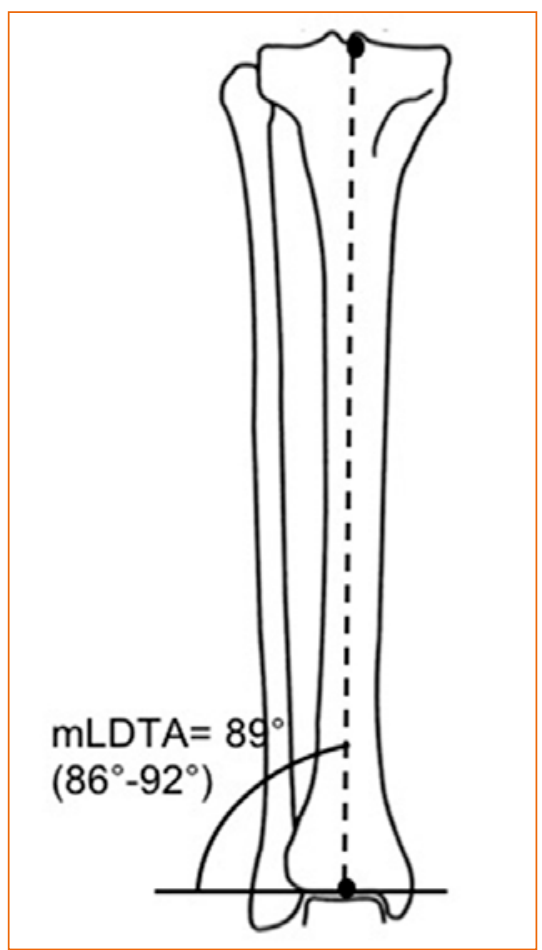

Şekil 17. Tibia distal mekanik aksı.

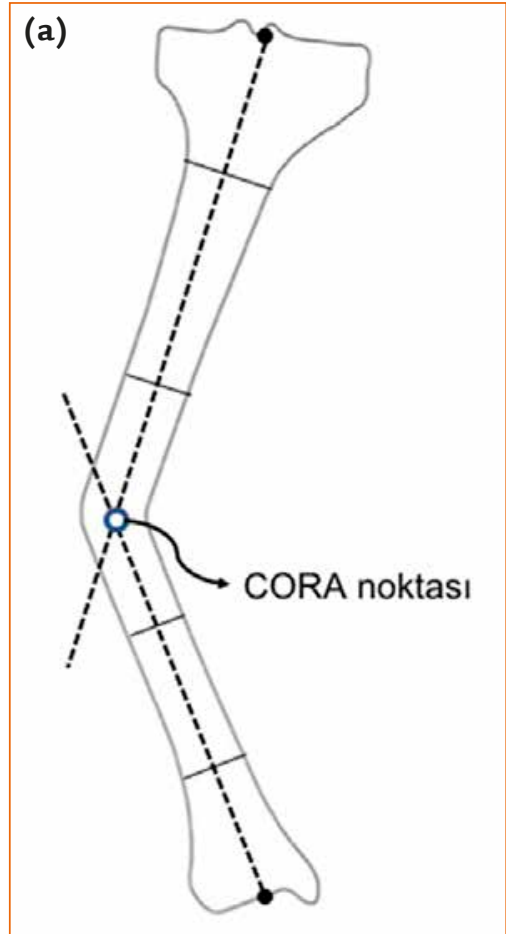

(b)

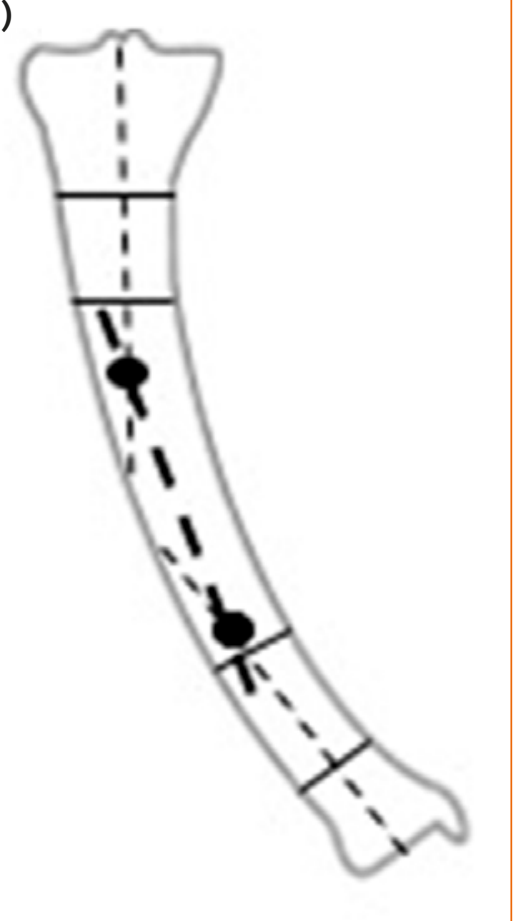

Şekil 18. a, b. Tibial deformite tek CORA noktası (a). Tibia birden fazla CORA noktası (b).

\section{Step (basamak) 3}

Deformitenin uniapikal ya da multiapikal olup olmadığına karar vermek için (Şekil 18),

1. CORA gerçek (görünür) deformite seviyesi ile aynı noktada ise tek planlı bir deformitedir ve deformite büyüklüğünü bu açı gösterir.

2. CORA görünür (gerçek) deformite seviyesi ile aynı noktada değilse ikinci bir deformite apeksi ya da translasyon deformitesi vardır. İkinci deformite apeksini bulmak için orta segmentten üçüncü mekanik aks çizgisi çizilmektedir. Deformite büyüklüğü bu iki deformite toplamına eşit olmaktadır.

Tibia frontal plan deformitelerinin anatomik aksa göre planlaması mekanik aksa göre planlama prensiplerine benzemektedir.

\section{Femoral Deformite Mekanik Aks Planlaması}

\section{Step (basamak) 1}

Distal mekanik aks çizilmesi (Şekil 19);

1. Aynı taraf MPTA normal ise tibial mekanik aksı proksimale uzatılarak femur distal segmentinin mekanik aksı oluşturulmaktadır.
2. Aynı taraf MPTA normal değerlerin dışında, karşı taraf mLDFA normal ise Femur distal eklem oryantasyon çizgisinin orta noktasından karşı taraf mLDFA değeri kullanılarak distal segmentin mekanik aksı çizilir.

3. Hem aynı taraf MPTA hem de karşı taraf mLDFA normal sınırların dışında ise femur distal eklem oryantasyon çizgisinin orta noktasından mLDFA ortalama değeri olan $87^{\circ}$ 'lik açı kullanılarak distal segmentin mekanik aksı çizilir. ${ }^{[1-4]}$

\section{Step (basamak) 2}

Proksimal femur mekanik aks çizilmesi;

1. Normal proksimal femoral diafiz var ise: Proksimal segment mid-diyafizel çizgi çizilir. Sonra femur başı merkezinden geçen mid-diyafizel çizgiye paralel ikinci çizgi çizilir. Bu çizgiye paralel $7^{\circ}$ lik açı ile çizilen üçüncü çizgi proksimal segment mekanik aksını oluşturur.

2. Proksimal femoral deformite varlığında, karşı taraf LPFA normal değerinde ise template (şablon) olarak bu açı kulanılarak proksimal segment mekanik aksı çizilirken, karşı taraf LPFA normal değilse ortalama açı olan $90^{\circ}$ kullanılarak proksimal mekanik aks çizilir. 

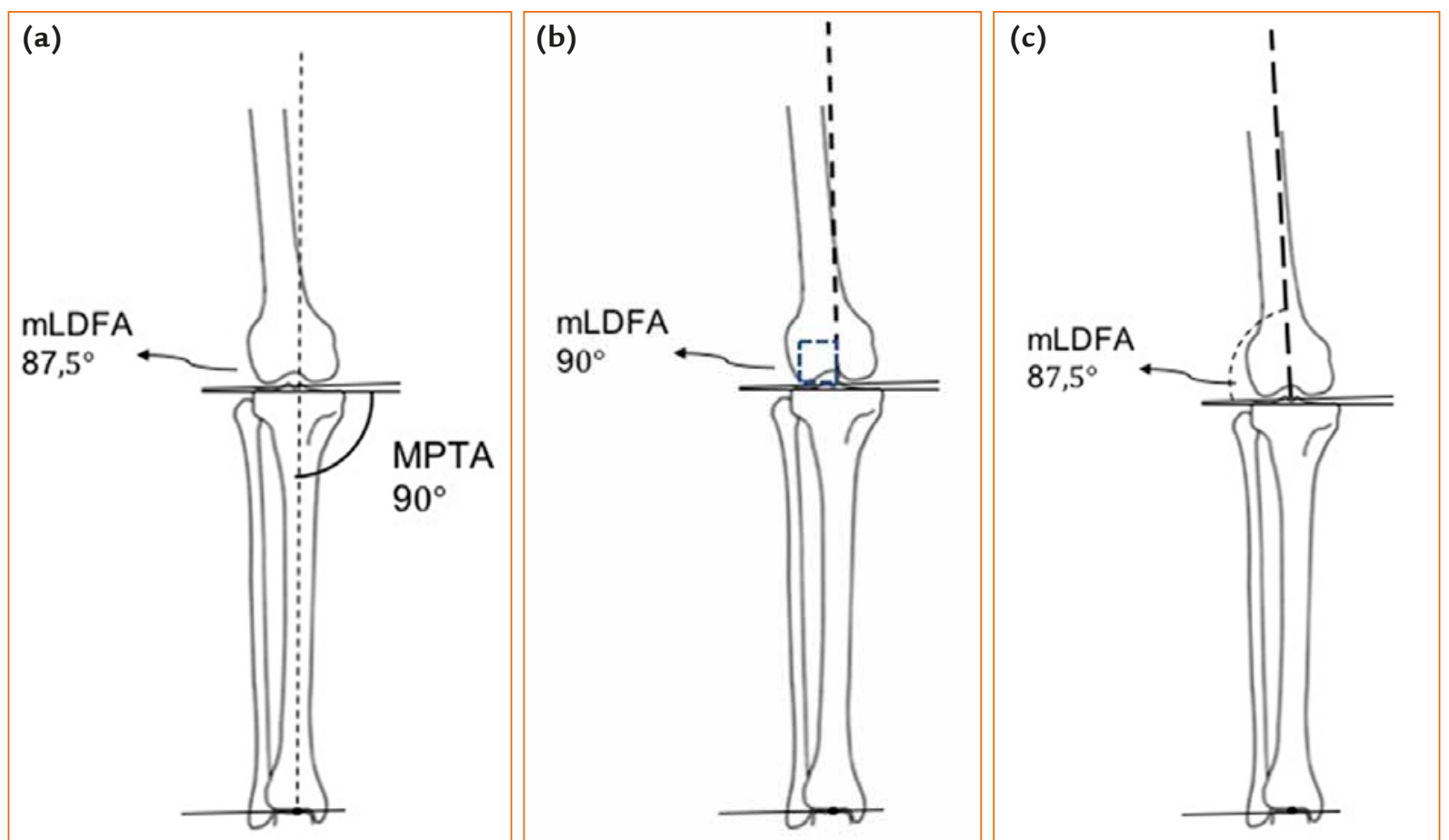

Şekil 19. a-c. Aynı taraf MPTA kullanılarak distal femur mekanik aks çizilmesi (a). Karşı taraf mLDFA kullanılarak distal femur mekanik aks çizilmesi (b). mLDFA ortalama değeri kullanılarak distal femur mekanik aks çizilmesi (c).

\section{Femoral Deformitenin Anatomik Aksa Göre Planlanması}

\section{Step (basamak) 1}

Femur mid-diyafizel çizgisi proksimal ve distal eklem oryantasyon çizgileri ile proksimalde MPFA $84^{\circ}$, distalde aLDFA $81^{\circ}$ olacak şekilde açı yapar ve bu normal femur olarak kabul edilir, Açılar normal değerlerin dışında ise femurda deformite aranır (Şekil 20).

\section{Step (basamak) 2}

1. Eğer anatomik aks çizisi ile femur distal oryantasyon çizgisinin yaptığı aLDFA normal ise femur distalinde deformite yok kabul edilirken, aLDFA normal değerlerin dışında ise, karşı taraf femur deforme değil ise onun aLDFA değeri kullanılarak distal segmentin anatomik aksı çizilir. Eğer karşı tarafta da deformite varsa aLDFA normal değeri kabul edilen $81^{\circ}$ ile distal femur anatomik aksı çizilir.

2. Eğer MPFA değeri normal sınırlar içinde ise femur proksimalinde deformite yok kabul edilirken, bu açı normal değerlerin dışında ise, karşı taraf femur MPFA değeri normal ise o değer, değilse MPFA'nın normal değeri olan $84^{\circ}$ kullanılarak kalça oryantasyon çizgisine göre proksimal femur anatomik aksı çizilir.

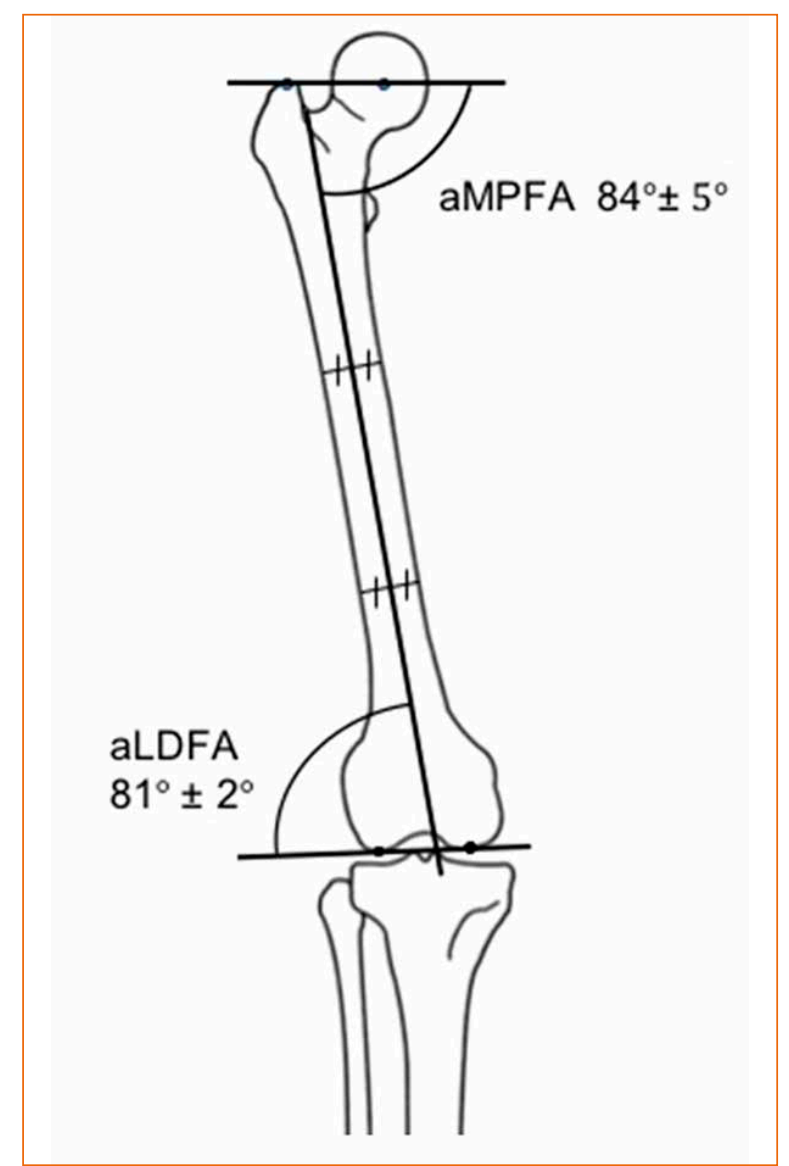

Şekil 20. Femoral anatomik aksa göre oryantasyon açıları. 


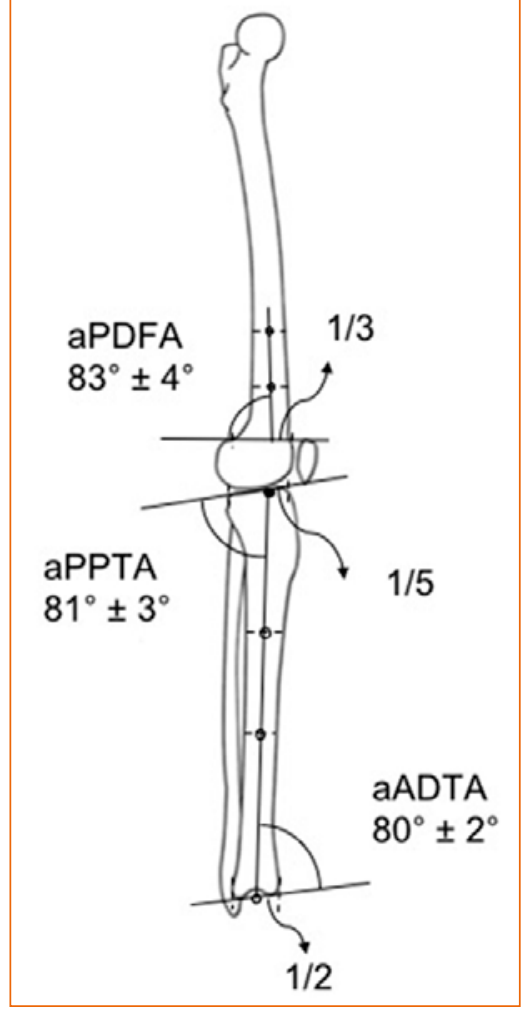

Şekil 21. Alt ekstremite sagittal plan mekanik aksı ve oryantasyon açıları.

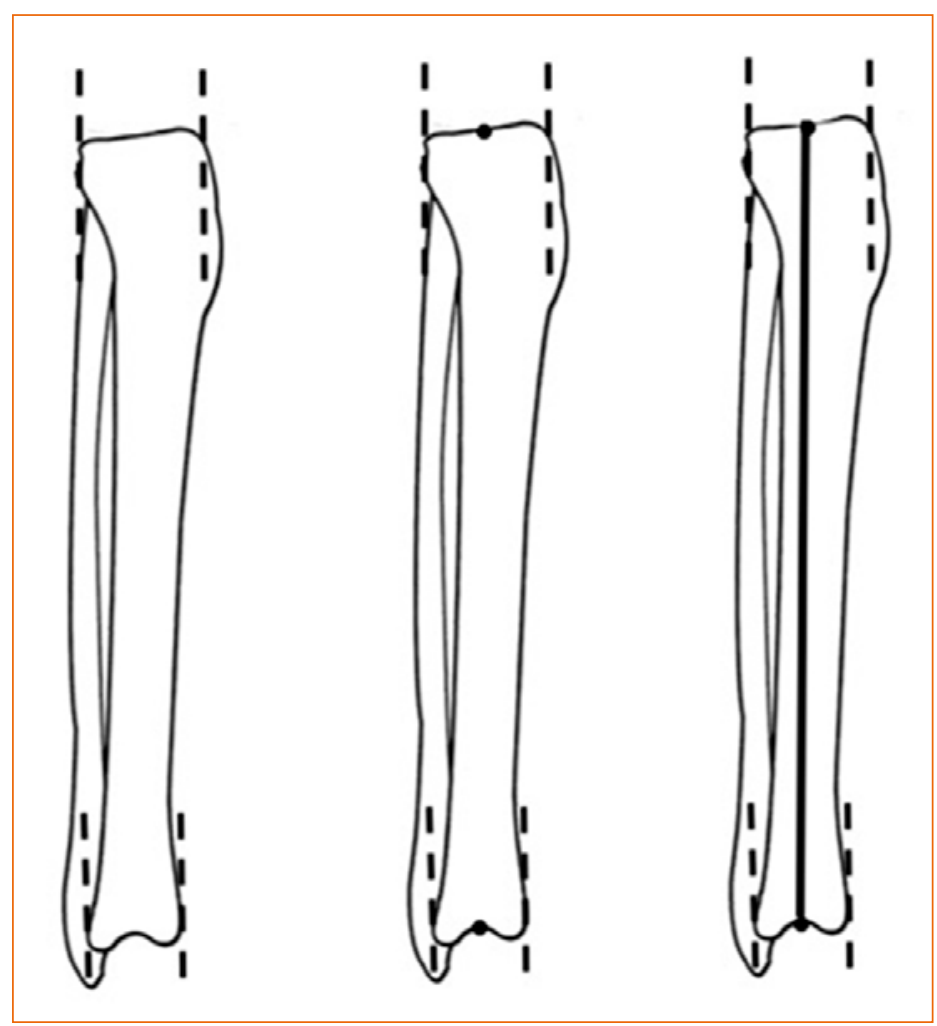

Şekil 22. Sagittal planda tibia mekanik ekseni ve oryantasyon açıları.

\section{Sagittal Plan Deformiteleri ve Maloryantasyon (Eklem Uyum) Testleri}

Diz frontal planda herhangi bir hareket aralığına sahip olmadığı için, MAD sabit olup kompansasyonu yoktur. Diz eklemi sagittal planda hareket ettiği için kalça, diz ve ayak bileğinin sagittal plandaki dizilimi normal diz hareketi ve yürüyüş sırasında değişiklik gösterir ve oluşan deformiteler belli derecelerde kompanse edilir. Genelde frontal plan deformitelerin analizinde statik değerlendirmeler yeterli olur iken, sagittal plan deformite değerlendirmelerinde dinamik faktörler de göz önüne alınmaktadır (Şekil 21). ${ }^{[3-5]}$

\section{Tibia Mekanik Ekseni Çizimi}

Sagittal planda tibia mekanik eksenini çizmek için tibia proksimal ve distal eklemlerinin merkezi bulunmalıdır. Lateral grafide tibia proksimal ve distal eklem yüzlerinin anterior ve posterior ucundan birer dik çizgi çizilir, bu dik çizgilerin orta noktası tibia proksimal ve distal eklem merkezlerini göstermektedir. Bu iki eklem merkez noktalarını birleştiren çizgi tibia mekanik ekseni olarak adlandırılır (Şekil 22).

\section{Tibia Anatomik Ekseni Çizimi}

Tibia diafizinde iki ya da üç diafiz orta noktası bulunup işaretlenir ve bunlar birleştirilerek tibia anatomik ekseni elde çizilir.

\section{Femur Mekanik Ekseni}

Sagittal planda femur mekanik eksen çizimi için, kalça ve diz rotasyon merkezi bulunmalıdır. Kalça rotasyon merkezi lateral grafide femur başı merkezidir. Diz rotasyon merkezi ise lateral grafide femur posterior korteksini devam ettiren çizginin Blumensaat çizgisi ile kesiştiği noktadır. Kalça ve diz rotasyon merkezleri birleştirilerek femur mekanik ekseni çizilmektedir (Şekil 23).

\section{Femur Anatomik Ekseni}

Femur sagittal planda konkavitesi anteriora olan anatomik eğriliğe sahiptir. Bu eğrilik nedeniyle, femur proksimal ve distal segmentlerinin anatomik ekseni ayrı ayrı çizilmelidir. İki anatomik eksen arasında $10^{\circ}$ 'lik açı vardır (Şekil 24). Bu açı sagittal plan korreksiyonlarında dikkate alınmalıdır. 


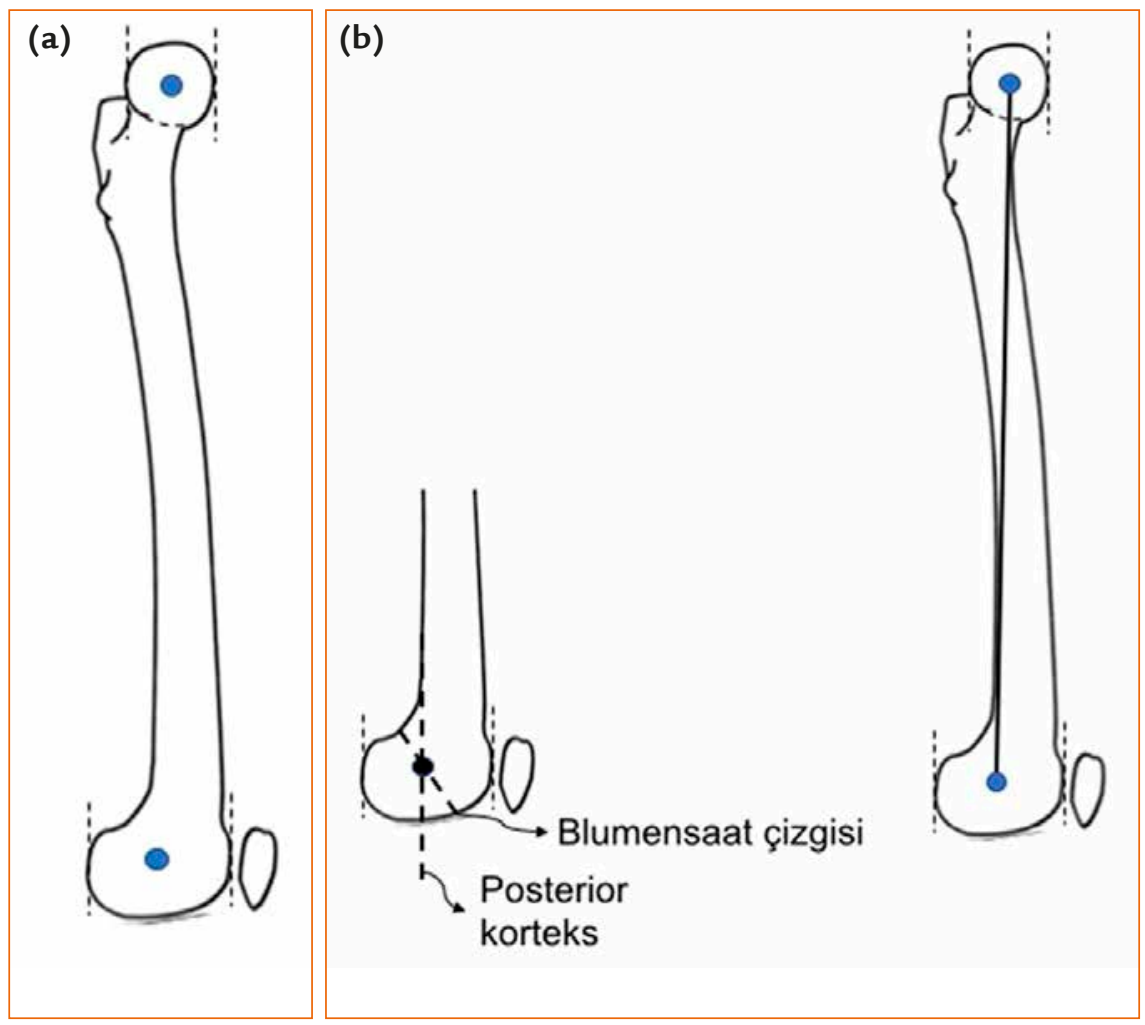

Şekil 23. a, b. Sagittal plan diz rotasyon merkezi (a). Sagittal planda femur mekanik ekseni ve oryantasyon açıları (b).
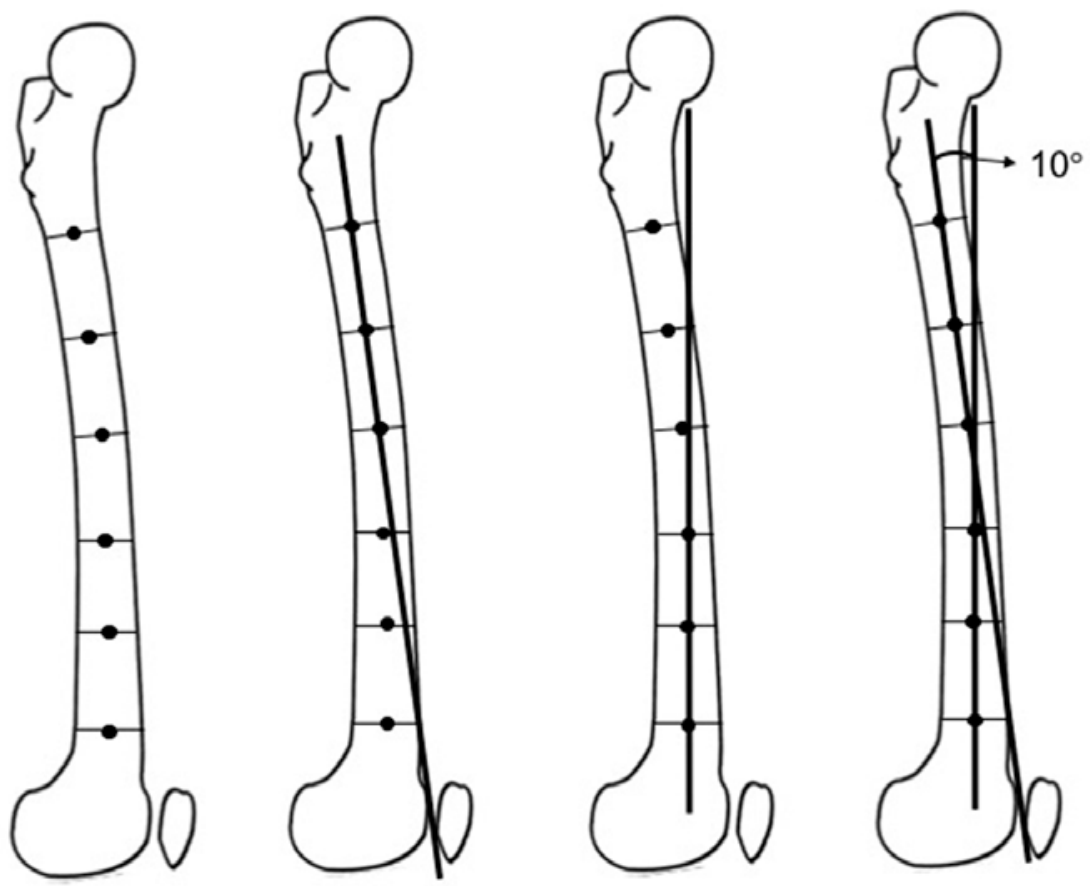

Şekil 24. Sagittal plan femur anatomik ekseni. 


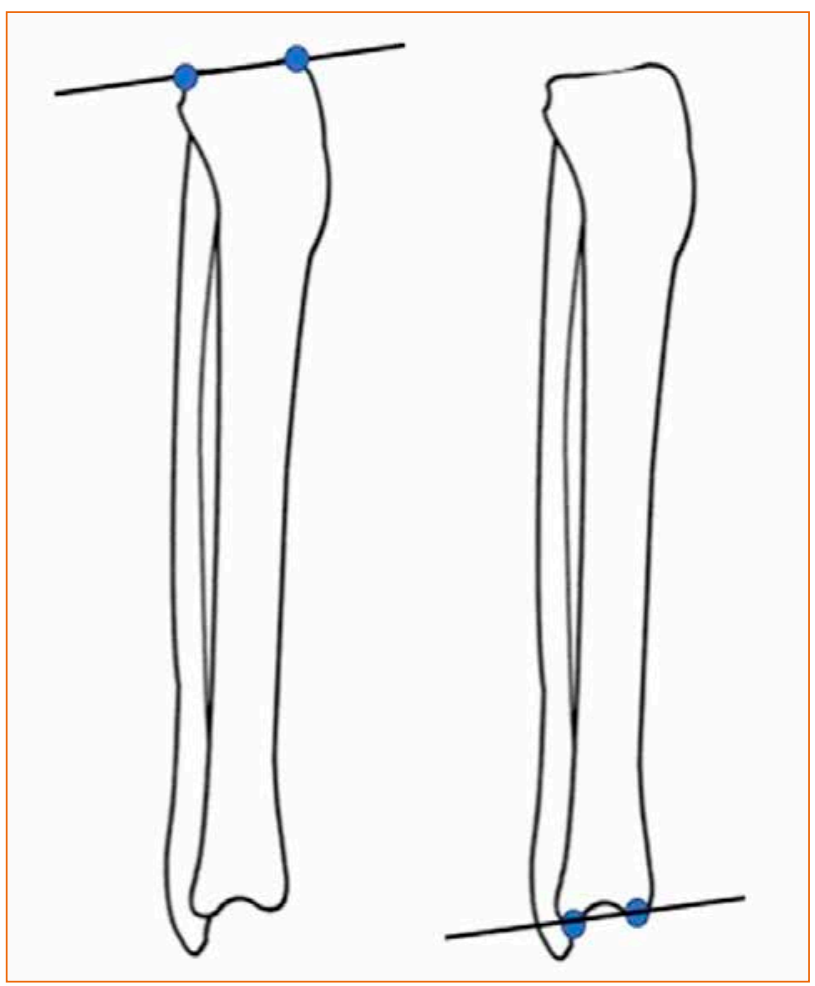

Şekil 25. Sagittal plan distal ve proksimal tibia oryantasyon çizgileri.

\section{Tibia Oryantasyon Çizgisi}

Proksimal tibia oryantasyon çizgisi platoların altında kalan düz subkondral hat olarak tariflenmektedir.

Distal tibia oryantasyon hattı ise tibianın anterior ve posterior dudaklarını birleştiren çizgidir (Şekil 25).

\section{Distal Femur Oryantasyon Çizgisi}

Çocuklarda büyüme plağının anterior ve en posterior noktalarını birleştiren çizgi oryantasyon çizgisidir. Büyüme plağı kapandıktan sonra büyüme kıkırdağının kalsifiye çizgisi esas alınarak oryantasyon çizgisi çizilirken, bununda kaybolduğu durumlarda femoral kondillerin metafizle birleştiği noktalar esas alınarak distal femurun sagittal plandaki oryantasyon hattı çizilir (Şekil 26).

\section{Anatomik ve Mekanik Eksenlerin Oryantasyon Hatları ile Oluşturduğu Açılar}

1. Anatomik posterior distal femur açı (aPDFA): Femur anatomik ekseni distal femur oryantasyon çizgisi ile posteriorda ortalama $83^{\circ}$ lik $\left(79^{\circ}-87^{\circ}\right)$ açı

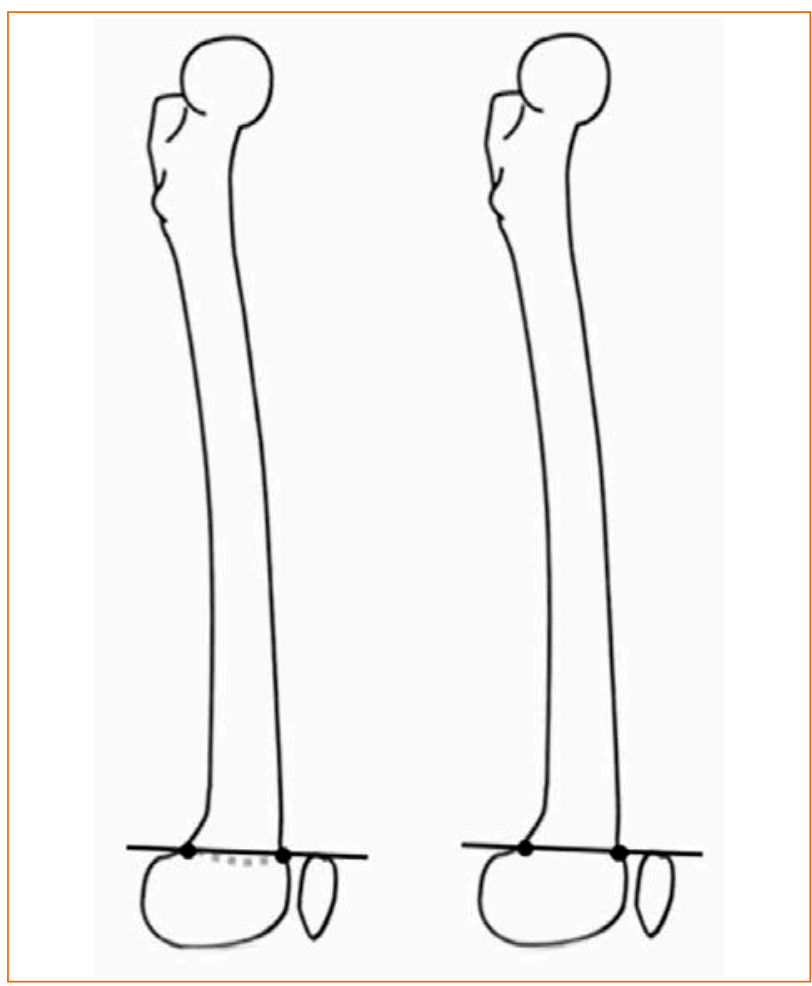

Şekil 26. Sagittal plan distal femur oryantasyon çizgisi.

yapar. Femur anatomik ekseni distal femur oryantasyon hattını $2 / 3$ anteriorda keser.

2. Anatomik posterior proksimal tibial açı (aPPTA): Sagittal planda tibia anatomik eksenin proksimal tibia eklem oryantasyon hattını kesmesi ile oluşan açı olarak tanımlanır. Tibia anatomik ekseni, proksimal eklem hattını $1 / 5$ anteriorunda kesmektedir. Bu açının değeri ortalama $81^{\circ}$ dir $\left(77^{\circ}-84^{\circ}\right)$.

3. Anatomik anterior distal tibial açı (aADTA): Sagittal plan distal tibia eklem oryantasyon çizgisi ile tibia anatomik ekseni tarafindan oluşturulur ve ortalama $80^{\circ}$ lik $\left(78^{\circ}-82^{\circ}\right)$ bir açıdır.

Sagittal planda frontal plandan farklı olarak kalça, diz ve ayak bileği eklemleri geniş hareket aralığına sahip olduğundan, bu planda olan deformiteler küçük açılarda tolere edilebilir. Bu özellikle rekurvatum, daha az olarak da prokurvatum deformitelerinin tolere edilmesinde görülmektedir.

\section{Alt Ekstremite Sagittal Plan Mekanik Ekseni}

Sagittal planda femur başı merkezi ile ayak bileği rotasyon merkezini (talusun lateral prosesi) birleştiren 


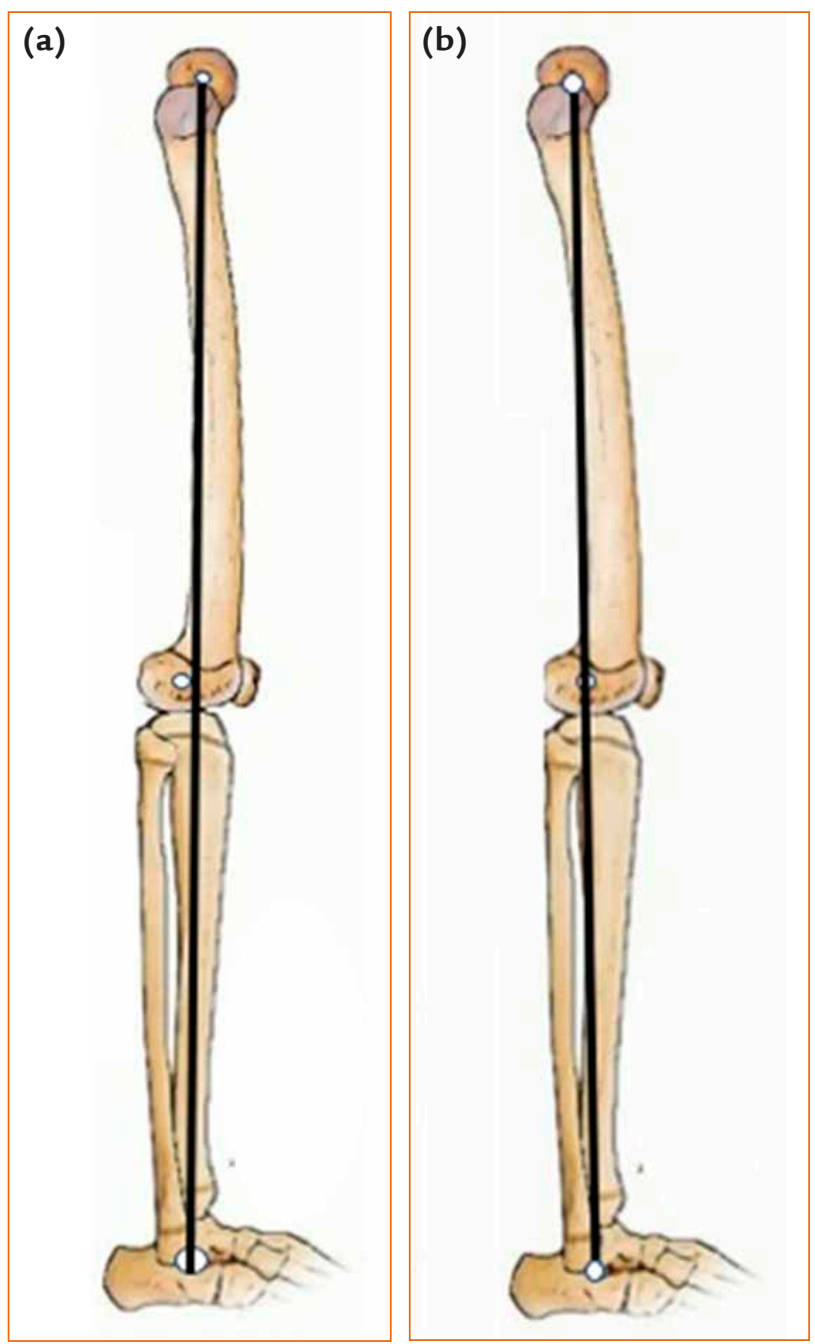

Şekil 27. a, b. Alt ekstremite sagittal plan mekanik ekseni. Diz tam ekstansiyonda (a). Diz 5-10 fleksiyonda (b).

çizgi alt ekstremitenin mekanik eksenidir. Diz tam ekstansiyonda iken, sagittal mekanik eksen diz ekleminin rotasyon merkezinin anteriorundan geçer. $\mathrm{Diz} 5^{\circ}-10^{\circ}$ fleksiyonunda iken mekanik aks diz rotasyon merkezinden geçer (Şekil 27).

\section{Sagittal Plan Malalignment Testi (MAT)}

Bu test sagittal planda deformite varlığını araştırmak için yapılmaktadır. MAT'ta özellikle fleksiyon ve ekstansiyon dizilim bozukluğu bulunup bulunmadığı araştırılmaktadır.

Fleksiyon dizilim bozukluğu: Normalde diz maksimum ekstansiyonda çekilen radyografide sagittal plandaki mekanik eksen, dizin rotasyon merkezinin posteriorundan geçmektedir. Fleksiyon dizilim bozukluğunda

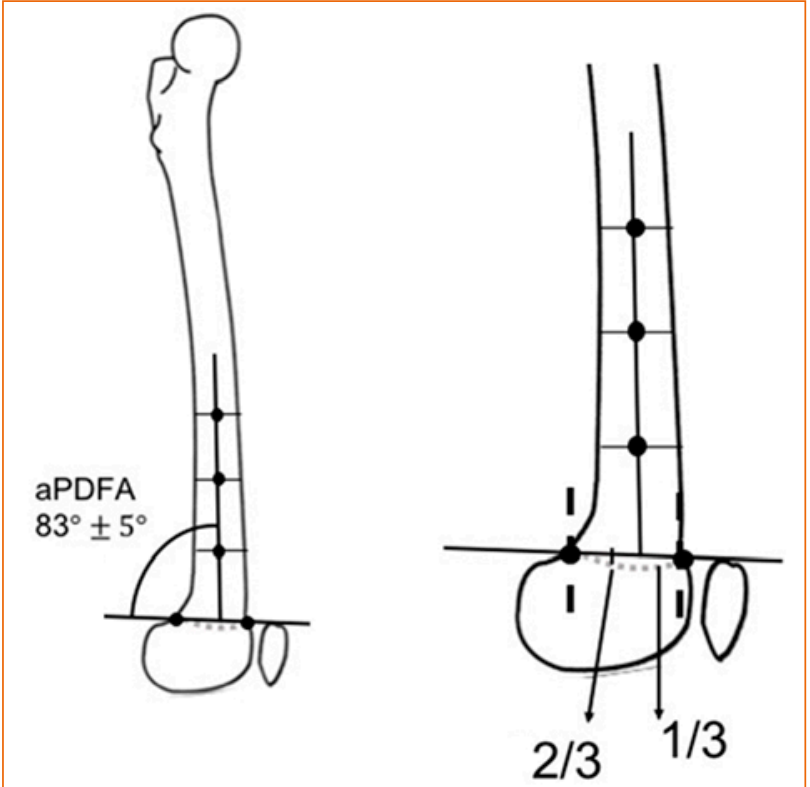

Şekil 28. Distal femur sagittal plan malalignment testi.

mekanik eksen diz rotasyon merkezinin anteriorunda geçmektedir.

Ekstansiyon dizilim bozukluğu: Sagittal planda diz pasif olarak $5^{\circ}$ 'den daha fazla ekstansiyona getirilebiliyorsa ekstansiyon dizilim bozukluğu olarak tanımlanmaktadır. ${ }^{[2-5]}$

\section{Sagittal Plan Malalignment Test (MAT)}

\section{Test 1}

$\mathrm{Bu}$ test ile femur distalinde deformite varlığı araştırılır.

1. Femur distal segment anatomik aksı çizilir.

2. Distal femur oryantasyon hattı çizilir.

3. Bu iki çizgi kesişimi ile oluşan açı posterior distal femoral açıdır (PDFA). Bu açının normal değeri ortalama $83^{\circ} \mathrm{dir}\left(78^{\circ}-88^{\circ}\right)$ (Şekil 28)

\section{Test 2}

Sagittal planda proksimal tibia deformite varlığı araştırılmaktadır

a. Tibia anatomik ekseni çizilir.

b. Proksimal tibia eklem oryantasyon hattı çizilerek anatomik posterior proksimal tibial açı (aPPTA) elde edilir. Bu açı $77^{\circ}$ 'den küçükse, prokurvatum deformitesi, $85^{\circ}$ 'den büyükse rekurvatum deformitesi tanısı konulmaktadır (Şekil 29). 


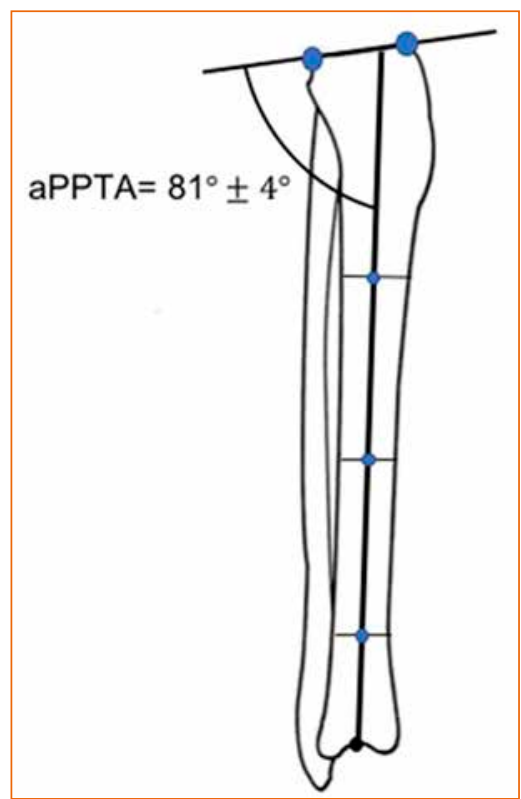

Şekil 29. Proksimal tibia sagittal plan malalignment testi.

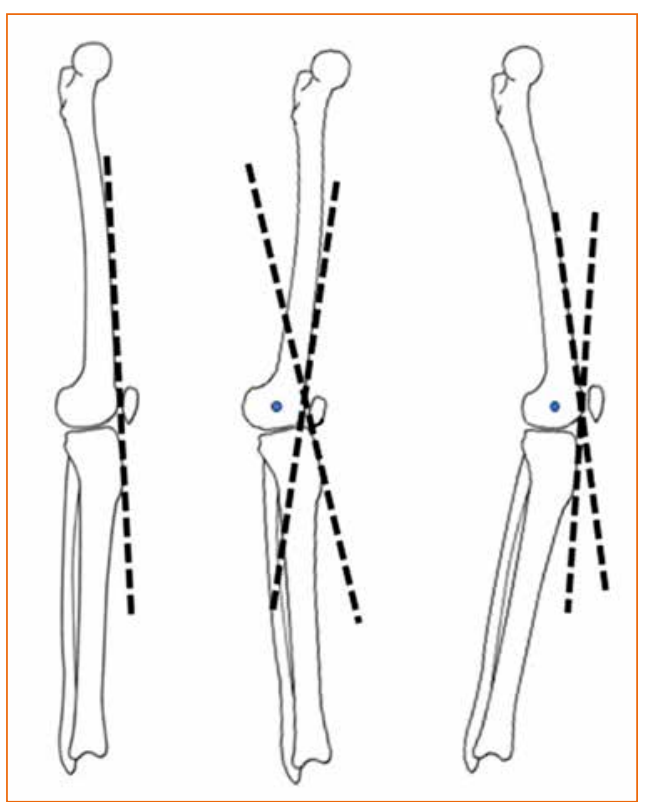

Şekil 30. Sagittal plan diz eklem kontraktür testi.

\section{Test 3}

Diz ekleminde kontraktür varlığını araştıran testdir. Diz tam ekstansiyonda çekilen ortoröntgenogramda femur distal anterior korteksinden çizilen çizgi ile proksimal tibianın anterior korteksinden çizilen çizgi açılanmadan ve birbirini kesmeden devam etmektedir. Bu iki çizgi arasında var olan açının yönüne göre fleksiyon ya da ekstansiyon dizilim bozukluğu tanısı konmaktadır (Şekil 30).

\section{Oblik Plan Deformitesi}

Anguler deformite herhangi bir planda olabilir. Standart referans plan frontal (koronal) ve sagittal plandır. Bu planlara denk gelen standart referans radyografileri ise sırası ile ön-arka (AP) ve yan (LAT) radyografilerdir. Hem ön-arka (frontal) hem de lateral (sagittal) radyografilerde açılanma varsa bu biplanar deformite olup buna oblik plan deformitesi adı verilir (Şekil 31). ${ }^{6-10]}$

Açısal deformitelerin apeksi iki farklı planda olabilir. Frontal plan için medial ve lateral (varus, valgus), sagittal plan için anterior ve posterior (prokurvatum, rekurvatum) olmak üzere her düzlem için iki olasılık vardır. ${ }^{[11-14]}$

Oblik plan deformitelerin hesaplanmasında grafik yöntemi kullanılmaktadır (Şekil 32).

Step (Basamak) 1: Grafik metodunda $X$ düzlemi frontal planı, $Y$ düzlemi ise sagittal planı göstermektedir.

Step (Basamak) 2: $X-Y$ düzlemi deformite apeksine göre dört harfle ifade edilir ( $\mathrm{A}$, anterior; $\mathrm{P}$, posterior; $\mathrm{M}$, medial; L, lateral)

Step (Basamak) 3: X-Y düzleminde angulasyon açısı yerleştirilirken $1 \mathrm{~mm}=1^{\circ}$ olarak işaretlenir.

Step 4: Oblik plan deformitesinde, frontal planda olan deformite $X$ aksına, sagittal planda olan $Y$ aksına işaretlenir. Ekstremitenin sağ ya da sol olmasına göre grafik düzlemine yerleştirilir. Grafiğin tabanı ise transvers planı gösterir. $X$ ekseninin sağ tarafi $(+)$, sol tarafi $(-)$, Y ekseninin ön tarafı (+) arka taraf (-) olarak işaretlenir. Bunların açıortayı oblik plan deformitesini verir.

Oblik planda yer alan deformiteler ise bunların birleşimi olarak dört şekilde görülür.

1. AM: Anteromedial; Anterior ve medial arasında yönelim gösterir. (varus ve prokurvatum).

2. AL: Anterolateral; Anterior ve lateral arasında yönelim gösterir, (valgus ve prokurvatum).

3. PM: Posteromedial; Posterior ve medial arasında yönelim gösterir. (varus ve rekurvatum).

4. PL: Posterolateral; Posterior ve lateral arasında yönelim gösterir. (valgus ve rekurvatum).

Grafik üzerinde yönler belirlenirken, planlayıcı kendi bacağına bakar, eğer hastada deformite sağ bacakta 


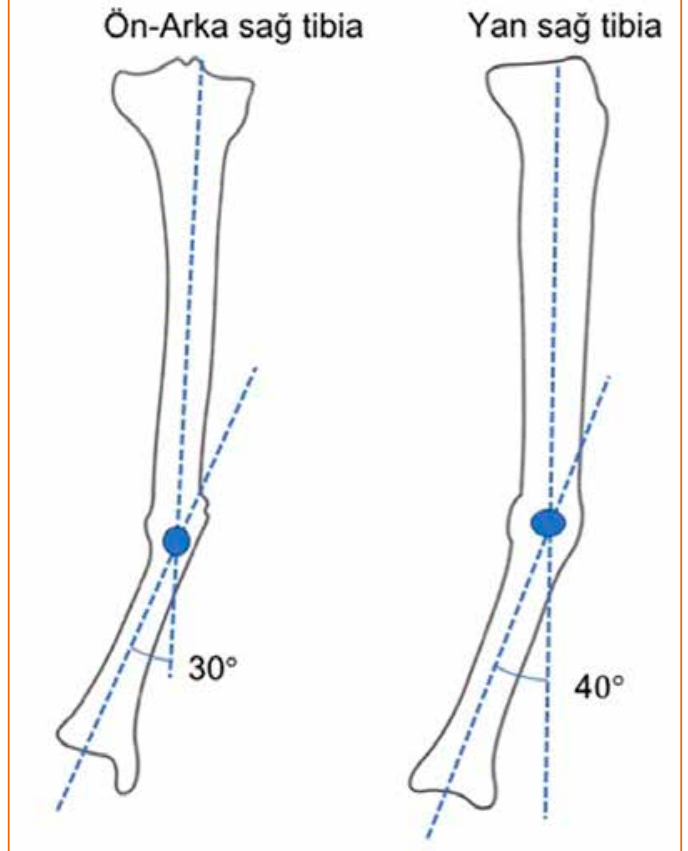

Şekil 31. Oblik plan deformitesi.

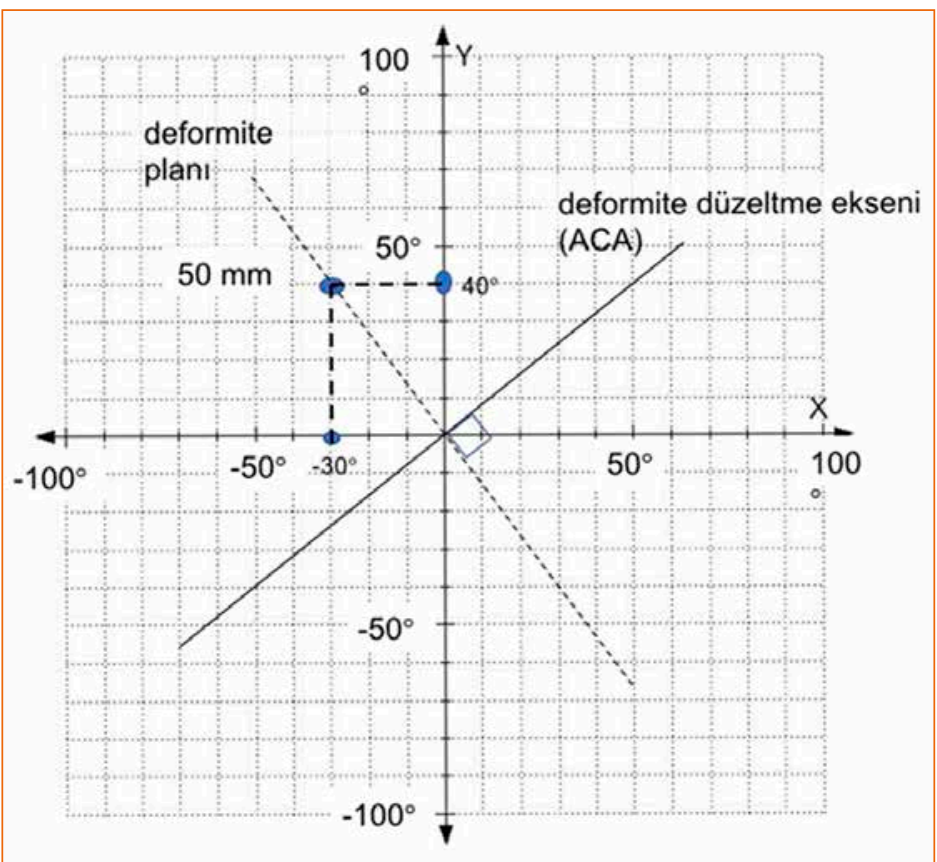

Şekil 32. Oblik plan deformitesinde grafik yöntemi. ise, kendi sağ bacağının iç ve dış tarafına uygun olarak yönleri belirler. Ön ve arka yön, sağ ve sol ekstremite için değişmezken, sağ ve sol ekstremitede iç ve dış yön, sağ ve sol tarafa göre değişir.

Sağ taraf için: $x$ ekseninin $(+)$ tarafi lateral, $(-)$ tarafı medial, y ekseninin $(+)$ tarafı anterior, $(-)$ tarafı posterior

Sol taraf için: $x$ ekseninin $(+)$ tarafı medial, (-) tarafı lateral, y ekseninin (+) tarafı anteriör, (-) tarafı posterior olarak $X-Y$ düzlemine işaretlenir.

\section{Deformitenin gerçek açısı, yönü ve planının saptanması}

$X$ ve $Y$ eksenindeki açı değerlerinin işaretlendiği noktalardan birer dikme çıkılır. Grafiğin orijini ile bu iki dikmenin kesişme noktasını birleştiren çizginin uzunluğunu ölçerek deformitenin gerçek açısı tespit edilmektedir. Bu çizginin yönü açılanmanın yönünü ve deformite planını gösterir.

Deformite planı bulunduktan sonra, bu çizgi ile $X$ ve $Y$ eksenleri arasındaki açı ölçülür. Bu çizgi ile $X$ ekseni arasındaki açı deformitenin frontal düzleme göre hangi planda yer aldığını gösterir.

\section{Deformite düzeltme ekseninin bulunması}

Orijinden geçen ve deformite planına dik olan bir doğru çizilir. Buna deformite düzeltme ekseni (ACA) denir. ACA kemiğin tam ortasından geçerse nötral kama osteotomisi, ACA kemiğin konkav tarafından geçerse kapalı kama osteotomisi, ACA kemiğin konveks tarafından geçerse açık kama osteotomisi gerçekleşmiş olmaktadır.

\section{Translasyon Deformitesi}

Translasyon deformitesi distal parçanın, proksimal parçaya göre yer değiştirmesidir. Translasyon deformitesi ya tek başına ya da angulasyon deformitesi ile birlikte de olabilir. Buna angulasyon-translasyon deformitesi denir. ${ }^{[7,15-18]}$

Translasyon deformiteleri: Frontal, sagittal ve oblik planda oluşabilir. Translasyon yönü distal kemiğin proksimal uca olan pozisyonuna göre belirlenir. ${ }^{[19,20]}$

a. Frontal planda translasyon: Ön-arka radyografide translasyon görünür iken yan radyografide translasyon görünmez. Frontal planda translasyon ya medial ya da lateral olarak gerçekleşir.

b. Sagittal planda translasyon: Ön-arka radyografide translasyon görünmez, her iki fragman ayn hizada görünür. Yan radyografide ise translasyon görünür ve yönü anterior ya da posteriora doğru olur.

c. Oblik planda translasyon: Hem ön-arka hem de yan radyografide fragmanlar arasında deplasman 
görünür. Oblik planda translasyon anterolateral, anteromedial, posterolateral, posteromedial yöne olabilir.

Deformite planlamasında ve analizinde temel olarak mekanik ve anatomik akslar ve eklem oryantasyon çizgilerinin bilinmesi, var olan frontal, sagittal, oblik ve translasyon deformitelerinin tespiti ve analizinin tam olarak yapılmasını sağlamaktadır. Bir deformite cerrahı öncelikle bu temel prensipleri bilmeli, sonrasında eğer gerek duyarsa dijital deformite düzeltme yöntemlerini öğrenmeli ve uygulamalıdır.

\section{KAYNAKLAR}

1. Paley D. Normal lower limb alignment and joint orientation. In: Paley D. Principles of Deformity Correction. Berlin: Springer-Verlag; 2005. pp.1-18.

2. Paley D. Frontal plane mechanical and anatomic axis planning. In: Paley D. Principles of Deformity Correction. Berlin: Springer-Verlag; 2005. pp.61-97.

3. Çakmak M, Özkan K. Alt Ekstremite Deformite Analizi (I). TOTBID (Türk Ortopedi ve Travmatoloji Birliği Derneği) Derg 2005;4(1-2):50-61. https://docplayer.biz.tr/115703-Altekstremite-deformite-analizi-i.html

4. Spiegelberg B, Parratt T, Dheerendra SK, Khan WS, Jenning R, Marsh DR. Ilizarov Principles of Deformity Correction. Ann R Coll Surg Engl 2010;92(2):101-5. Crossref

5. Paley D. Sagital plane deformities. In: Paley D. Principles of Deformity Correction. Berlin: Springer-Verlag; 2005. pp.155-74.

6. Paley D. Oblique plane deformities. In: Paley D. Principles of Deformity Correction. Berlin: Springer-Verlag; 2005. pp.175-93.

7. Çakmak M, Özkan K. Alt Ekstremite Deformite Analizi (II) Oblik Plan Translasyon Deformiteleri. TOTBID (Türk Ortopedi ve Travmatoloji Birliği Derneği) Derg 2005;4(3-4):118-26. https://docplayer.biz.tr/10395056-Alt-ekstremite-deformiteanalizi-ii-oblik-plan-ve-translasyon-deformiteleri.html

8. Paley D. Translation and angulation-translation deformities. In: Paley D. Principles of Deformity Correction. Berlin: Springer-Verlag; 2005. pp.195-234.

9. Dahl MT, Morrison SG, Georgiadis AG, Huser AJ. What's New in Limb Lengthening and Deformity Correction. J Bone Joint Surg Am 2019;101(16):1435-9. Crossref
10. Schröter S, Elson DW, Ateschrang A, Ihle C, Stöckle U, Dickschas J, Harrer J. Lower Limb Deformity Analysis and the Planning of an Osteotomy. J Knee Surg 2017;30(5):393-408. Crossref

11. Hamdy RC, Bernstein M, Fragomen AT, Rozbruch SR. What's New in Limb Lengthening and Deformity Correction. J Bone Joint Surg Am 2016;17;98(16):1408-15. Crossref

12. Sabharwal S, Nelson SC, Sontich JK. What's New in Limb Lengthening and Deformity Correction. J Bone Joint Surg Am 2015;19;97(16):1375-84. Crossref

13. Küçükkaya $M$, Karakoyun $O$, Armağan $R$, Kuzgun $U$. Correction of complex lower extremity deformities with the use of the Ilizarov-Taylor spatial frame. Acta Orthop Traumatol Turc 2009;43(1):1-6. http://www.aott.org.tr/en/ correction-of-complex-lower-extremity-deformities-with-theuse-of-the-ilizarovtaylor-spatial-frame-164503

14. Mosca VS. Principles of Lower Extremity Deformity Correction in Children. J Pediatr Orthop 2017;37:S9-11. https://doi. org/10.1097/bpo.0000000000001028

15. Mayer SW, Hubbard EW, Sun D, Lark RK, Fitch RD. Gradual Deformity Correction in Blount Disease. J Pediatr Orthop 2019;39(5):257-62. Crossref

16. Li QW, Song HR, Mahajan RH, Suh SW, Lee SH. Deformity correction with external fixator in pseudoachondroplasia. Clin Orthop Relat Res 2007;454:174-9. Crossref

17. Horn J, Hvid I, Huhnstock S, Breen AB, Steen H. Limb lengthening and deformity correction with externally controlled motorized intramedullary nails: evaluation of 50 consecutive lengthenings. Acta Orthop 2019;90(1):81-7. Crossref

18. Eralp L, Kocaoglu M, Toker B, Balcı HI, Awad A. Comparison of fixator-assisted nailing versus circular external fixator for bone realignment of lower extremity angular deformities in rickets disease. Arch Orthop Trauma Surg 2011;131(5):5819. Crossref

19. Başbozkurt M, Yildiz $C$, Kömürcü $M$, Demiralp $B$, Kürklü $M$, Ateşalp AS. Management of fibular hemimelia with the Ilizarov circular external fixator. Acta Orthop Traumatol Turc 2005;39(1):46-53. http://www.aott.org.tr/en/managementof-fibular-hemimelia-with-the-ilizarov-circular-externalfixator-164731

20. Wahab H, Fahad S, Noor-Us-Sabah TA, Mohib Y, Ur Rashid $\mathrm{H}$, Umer M. Correction of lower limb deformities with fixator assisted nailing. Ann Med Surg (Lond) 2019;8(45):40-4. Crossref 